\title{
Machine Learning Applied to K-Bentonite Geochemistry for Identification and Correlation: The Ordovician Hagan K-Bentonite Complex Case Study
}

\author{
Achim D. Herrmann ${ }^{1, *}$, John T. Haynes ${ }^{2}{ }^{\mathbb{D}}$, Richard M. Robinet ${ }^{1}$ and Norlene R. Emerson ${ }^{3}$ \\ 1 Department of Geology \& Geophysics and Coastal Studies Institute, Louisiana State University, \\ Baton Rouge, LA 70803, USA; rrobi65@lsu.edu \\ 2 Department of Geology and Environmental Science, James Madison University, MSC 6903, \\ Harrisonburg, VA 22807, USA; haynesjx@jmu.edu \\ 3 Department of Geography \& Geology, University of Wisconsin-Richland, Richland Center, WI 5358, USA; \\ emersonn@uwplatt.edu \\ * Correspondence: aherrmann@lsu.edu; Tel.: +1-225-578-3016
}

\section{check for} updates

Citation: Herrmann, A.D.; Haynes, J.T.; Robinet, R.M.; Emerson, N.R. Machine Learning Applied to K-Bentonite Geochemistry for Identification and Correlation: The Ordovician Hagan K-Bentonite Complex Case Study. Geosciences 2021, 11, 380. https://doi.org/ 10.3390 /geosciences 11090380

Academic Editors: Roberto Moretti and Jesus Martinez-Frias

Received: 23 July 2021

Accepted: 31 August 2021

Published: 9 September 2021

Publisher's Note: MDPI stays neutral with regard to jurisdictional claims in published maps and institutional affiliations.

Copyright: (c) 2021 by the authors. Licensee MDPI, Basel, Switzerland. This article is an open access article distributed under the terms and conditions of the Creative Commons Attribution (CC BY) license (https:/ / creativecommons.org/licenses/by/ $4.0 /)$.

\begin{abstract}
Altered tephras (K-bentonites) are of great importance for calibration of the geologic time scale, for local, regional, and global correlations, and paleoenvironmental reconstructions. Thus, definitive identification of individual tephras is critical. Single crystal geochemistry has been used to differentiate tephra layers, and apatite is one of the phenocrysts commonly occurring in tephras that has been widely used. Here, we use existing and newly acquired analytical datasets (electron probe micro-analyzer [EPMA] data and laser ablation ICP-MS [LA-ICP-MS] data, respectively) of apatite in several Ordovician K-bentonites that were collected from localities about $1200 \mathrm{~km}$ apart (Minnesota/Iowa/Wisconsin and Alabama, United States) to test the use of machine-learning (ML) techniques to identify with confidence individual tephra layers. Our results show that the decision tree based on EPMA data uses the elemental concentration patterns of $\mathrm{Mg}, \mathrm{Mn}$, and $\mathrm{Cl}$, consistent with previous studies that emphasizes the utility of these elements for distinguishing Ordovician K-bentonites. Differences in the experimental setups of the analyses, however, can lead to offsets in absolute elemental concentrations that can have a significant impact on the correct identification and correlation of individual K-bentonite beds. The ML model using LA-ICP-MS data was able to identify several K-bentonites in the southern Appalachians and establish links to K-bentonites samples from the Upper Mississippi Valley. Furthermore, the ML model identified individual layers of multiphase eruptions, thus illustrating very well the great potential of applying ML techniques to tephrochronology.
\end{abstract}

Keywords: tephrochronology; tephrostratigraphy; tephra fingerprinting; Deicke; Millbrig; Dickeyville; Elkport

\section{Introduction}

The geochemistry of igneous apatite is complex, and in response to various magmatic conditions during crystallization (e.g., oxygen fugacity, temperature, crystallization rate, chemical composition), its trace-element composition can acquire a characteristic geochemical fingerprint [1,2]. Because of this, the geochemistry of apatite is a powerful tool for testing tectonostratigraphic hypotheses and for the high-resolution correlation of pyroclastics produced by large volcanic eruptions, as demonstrated by its successful use in many investigations of tephras ranging in age from the Paleozoic to the recent Cenozoic [3-6].

Explosive volcanism during the later Ordovician (470-445 Ma; Figures 1 and 2) resulted in many airfall deposits of volcanic ash being spread across much of what is now eastern North America [7-9], northern Eurasia [10,11], and western South America [12]. It has long been recognized that the geochemistry of these Ordovician K-bentonites can 
be used for high-resolution stratigraphy $[4,13]$. The tephrochronological approach has led to development of a high-resolution framework useful for identifying and correlating stratigraphic packages that are otherwise difficult to identify. For instance, much stratigraphic correlation in the northern part of Laurentia (Figure 1) is based on K-bentonite tephrostratigraphy $[4,5,14,15]$. Most importantly, a high-resolution stratigraphic framework based on apatite phenocryst geochemistry facilitates testing of stratigraphic and geological hypotheses, e.g., apatite geochemistry provided evidence that the stratigraphic changes across the Sandbian-Katian boundary are time-transgressive across part of the Appalachian basin and therefore are most likely not global events [5].

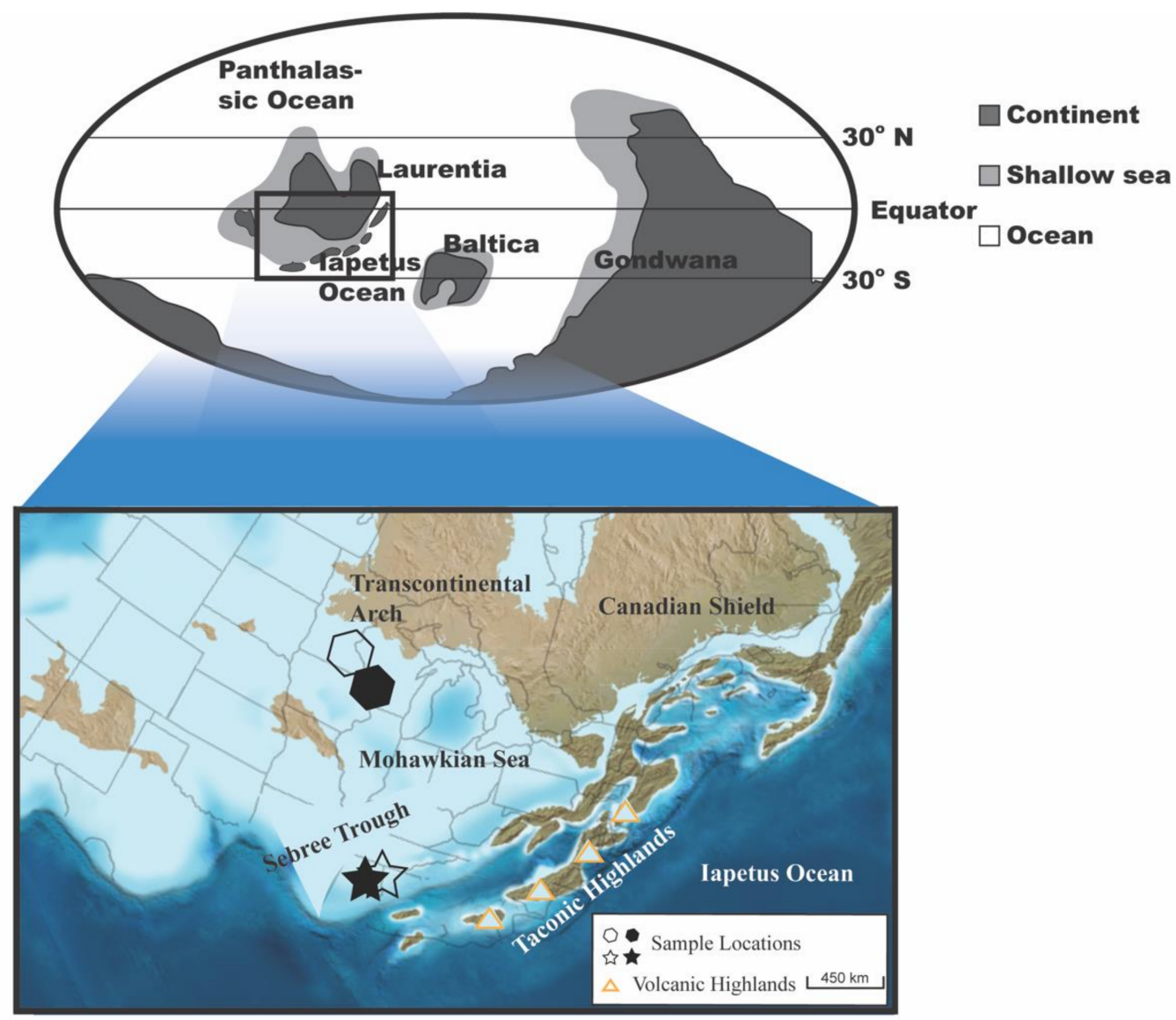

Figure 1. Paleogeographic setting: Full star-location of Big Ridge and Bruton Gap sections, open star-location of Tidwell Hollow and Fort Payne sections, all in Alabama, full octagon-location of Decorah and Dickeyville sections, open octagon-location of Rochester and St. Paul sections, both in Minnesota. Regional Ordovician paleogeography modified from [22].

Those tephras, several of which were generated by arguably the largest explosive volcanic eruptions in the Phanerozoic, have been altered to K-bentonites, including three of the K-bentonite beds in the Hagan K-bentonite complex [16] of eastern North America (Deicke, Millbrig, and Elkport) that are the subject of our investigations reported herein. In recent years, machine-learning techniques (hereinafter ML) have been applied to volcanology $[17,18]$. Here, we test whether ML techniques can be applied to these deposits to enhance our ability to identify and correlate these eruptive events that could be used to track environmental and tectonic changes through time and space in order to test tectonostratigraphic hypotheses [5,19-21]. 
Big Ridge, Gadsden, AL (34.139492 N 85.991043 W)

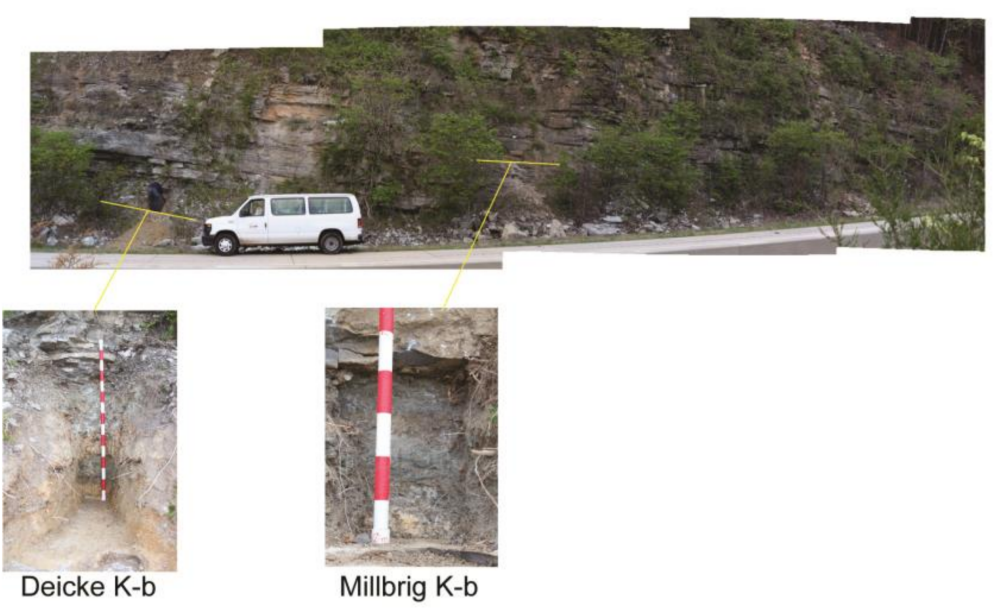

(a)

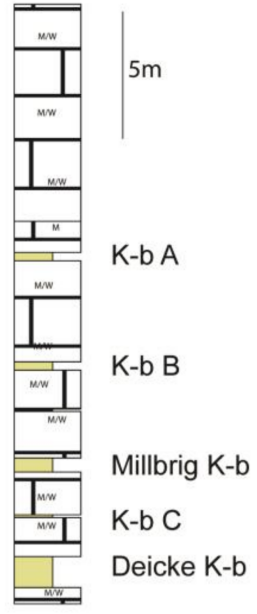

(b)

Figure 2. (a) The exposure of outcropping K-bentonites at Big Ridge, with insets of the Deicke and Millbrig K-bentonites showing the individual distinct layers that are evident subsequent to being completely excavated prior to collecting samples from each visibly different layer. (b) Stratigraphic column of the Big Ridge section, showing the stratigraphic horizons of individual K-bentonites used for developing the identification model using LA-ICP-MS data. K-b $=\mathrm{K}$-bentonite. Recessed intervals (yellow) are K-bentonites. M: Mudstone; M/W: Mud/Wackestone. Red and white intervals on Jacob's Staff are $10 \mathrm{~cm}$ each.

\section{Materials and Methods}

\subsection{Machine Learning Environment and Parameters}

We used the open-access machine-learning software WEKA [23,24] for these analyses. WEKA is widely used and has appropriate analytical tools for machine-learning applications for decision tree generation based on geochemical datasets [25]. Datasets were imported and, depending on the geochemical dataset, processed as follows. Datasets were processed similarly, as outlined below.

We built a model based on the Emerson et al. [15] dataset, which we call the "UMV (Upper Mississippi Valley)-Model" For developing this "UMV-Model", we used the J48 algorithm for generating our decision trees. The J48 algorithm is the java software implementation of the C4.5 classifier [26] in WEKA, and it is an algorithm that aims at choosing the particular attribute of the data which most effectively splits its set of samples into subsets at each node of the decision tree. The resulting decision tree was pruned by forcing 15 instanced into a leaf, thereby not overfitting the results. The dataset of Emerson et al. [15] is already published, and can be accessed through their manuscript location.

We also developed the "Big-Ridge-Model", which is based on laser ablation-inductively coupled plasma-mass spectrometry (hereinafter LA-ICP-MS) data of newly and previously reported apatite phenocrysts. We also used the J48 tree-building algorithm, and, as with the EPMA data, the resulting decision tree was pruned by forcing 15 instanced into a leaf, thereby not overfitting the results (Figure 3). The dataset is available in Appendix A. 


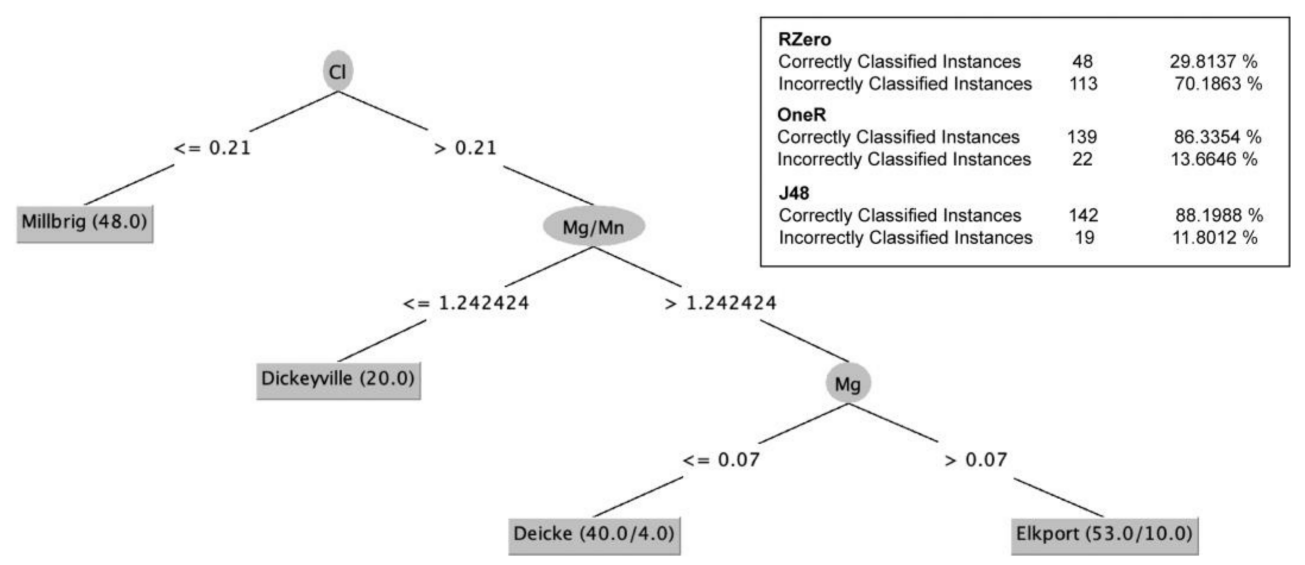

Figure 3. UMV-model decision tree of four prominent Ordovician K-bentonites using the J48 classifier. Shown in the inset are the percentages for correctly and incorrectly classified instances based on different decision modes. RZero: essentially guessing the most abundant class for every instance; OneR: classifying each instance based on only one variable.

\subsection{Training and Test Set for Geochemical Data Based on LA-ICP-MS Data of Ordovician K-Bentonites}

Table 1 presents the location information for the Ordovician K-bentonite samples in this study that were investigated using LA-ICP-MS of apatite phenocrysts and then used for the training and testing datasets for the laser ablation data. At Big Ridge (Figure 2), the Deicke K-bentonite was divided into seven visually distinct intervals (D1-D7 from base to top) and the Millbrig K-bentonite was divided into four evenly spaced and visually distinct intervals (M1-M4 from base to top).

Table 1. Location information for each sample, the name of each K-bentonite that was collected at each section, and the key references for each sample. "?" refers to K-bentonites that have been tentatively identified, but not yet geochemically fingerprinted.

\begin{tabular}{|c|c|c|c|}
\hline Location & K-Bentonite & Key Reference & GPS Location \\
\hline Big Ridge, Alabama & Deicke, Millbrig & [27] & $\begin{array}{c}\text { lat. } 34.13990 \mathrm{~N} \\
\text { long. } 85.99102 \mathrm{~W}\end{array}$ \\
\hline Decorah, Iowa & Deicke & [15] & $\begin{array}{c}\text { lat. } 43.290249 \mathrm{~N} \\
\text { long. } 91.765676 \mathrm{~W}\end{array}$ \\
\hline Dickeyville, Wisconsin & Millbrig, Elkport & [15] & $\begin{array}{c}\text { lat. } 42.661833 \mathrm{~N} \\
\text { long. } 90.656099 \mathrm{~W}\end{array}$ \\
\hline Rochester, Minnesota & Deicke, Millbrig & [15] & $\begin{array}{c}\text { lat. } 43.972161 \mathrm{~N} \\
\text { long. } 92.382820 \mathrm{~W}\end{array}$ \\
\hline St. Paul, Minnesota & Deicke, Millbrig & [28] & $\begin{array}{c}\text { lat. } 44.920746 \mathrm{~N} \\
\text { long. } 93.110729 \mathrm{~W}\end{array}$ \\
\hline Fort Payne, Alabama & $?$ & [29] & $\begin{array}{c}\text { lat. } 34.480380 \mathrm{~N} \\
\text { long. } 85.709067 \mathrm{~W}\end{array}$ \\
\hline $\begin{array}{c}\text { Tidwell Hollow, } \\
\text { Alabama }\end{array}$ & $?$ & [29] & $\begin{array}{c}\text { lat. } 33.87806 \mathrm{~N} \\
\text { long. } 86.57555 \mathrm{~W}\end{array}$ \\
\hline Bruton Gap, Alabama & $?$ & [30] & $\begin{array}{c}\text { lat. } 34.091294 \mathrm{~N} \\
\text { long. } 86.041315 \mathrm{~W}\end{array}$ \\
\hline
\end{tabular}

\subsection{Training Set for Geochemical Data Based on Electron Probe Micro-Analyzer (EPMA)}

We used the dataset of Emerson et al. [15] for the training set for testing the correlation of K-bentonites using existing EPMA data, and we used a subset of that dataset for the LA-ICP-MS test. That study focused on the geochemistry of apatite phenocrysts of four prominent Katian-Sandbian age K-bentonites recognized within the Decorah Formation in the upper Mississippi Valley states of Minnesota, Iowa, and Wisconsin (Figure 1). These K-bentonites are the Deicke, Millbrig, Elkport, and Dickeyville K-bentonites. Emerson et al. [15] reported results based on apatite phenocrysts that had been analyzed for 15 elements, and we are using only the datapoints that included $\mathrm{Mg}$ and $\mathrm{Mn}$ values, as these 
two elements had been identified before as being especially informative and important when using apatite geochemistry for stratigraphic purposes.

\subsection{Cross Calibration Datasets for Geochemical Data Based on Electron Probe Micro-Analyzer (EPMA)}

We evaluated the training model that was derived from the Emerson et al. [15] dataset with the dataset of Carey et al. [14]. Both studies analyzed distinct K-bentonite layers, some of which had previously been independently identified as the Deicke K-bentonite, or the Millbrig K-bentonite, through detailed correlation using wire-line logs, stratigraphic position, and (or) mineral content and geochemistry [7,30]. Thus, the Deicke and Millbrig samples from those studies are suitable for use as a test set, because their identification is confidently known. We used all analyzed elements and replaced missing values that were included in the Emerson et al. [15] dataset, but not in Carey et al. [14], as missing data values.

For data from the Carey et al. [14] study, we first focused on the Deicke and Millbrig K-bentonites to assess the accuracy of the UMV-model for identifying those two major K-bentonites. The dataset of Carey et al. [14] is also already published, and can be accessed through their manuscript location.

\subsection{LA-ICP-MS Analysis of Apatite Phenocrysts to Establish the Training and Testing Datasets}

We used the LA-ICP-MS data set from Big Ridge (Figure 1) for the training set (BigRidge-Model). These K-bentonites include the two thickest and most prominent ones that have previously been identified as the Deicke and Millbrig K-bentonite beds [30], as well as three previously unnamed $\mathrm{K}$-bentonites $(\mathrm{Kb}-\mathrm{A}, \mathrm{Kb}-\mathrm{B}$, and $\mathrm{Kb}-\mathrm{C}$. The LA-ICP-MS analyses were performed using a Thermo iCap Qc ICP-MS that was connected to a Cetac G2-213 Nd:YAG laser system in the Department of Geology and Geophysics at Louisiana State University. Isotopes of individual elements analyzed included ${ }^{24} \mathrm{Mg},{ }^{43} \mathrm{Ca},{ }^{55} \mathrm{Mn}$, ${ }^{57} \mathrm{Fe},{ }^{89} \mathrm{Y},{ }^{232} \mathrm{Th},{ }^{238} \mathrm{U}$ and the rare earth elements La-Lu. Elemental concentrations were normalized against the NIST612 glass standard, using ${ }^{43} \mathrm{Ca}$ as an internal standard using Iolite 2.5 [31]. During preprocessing, we eliminated data points with inclusions or other problems during the laser ablation session. Durango and Madagascar (MAD) apatites were used as secondary standards. Additional sample processing and analytical details were reported by Herrmann et al. [27]. The results of the LA-ICP-MS analyses used for the training set are tabulated in online Appendix A. The results of the LA-ICP-MS analyses for the testing set are tabulated in online Appendix B. The laser parameters for the individual runs are in Appendix $C$. The model was derived using the following 15 attributes based on elemental concentrations and different ratios: $\mathrm{Mg}, \mathrm{Mn}, \mathrm{Y}, \mathrm{U}, \mathrm{REEsum},(\mathrm{La} / \mathrm{Sm})_{\mathrm{N}},(\mathrm{La} / \mathrm{Yb})_{\mathrm{N}}$, $\mathrm{Pr} / \mathrm{Pr}^{*}, \mathrm{Ce} / \mathrm{Ce}^{*}, \mathrm{La} / \mathrm{La}^{*}, \mathrm{Eu} / \mathrm{Eu}^{*}, \mathrm{Mn} / \mathrm{Eu}^{*}, \mathrm{Mg} / \mathrm{Mn}, \mathrm{Ce}^{*} / \mathrm{Y}$, and $(\mathrm{Gd}+\mathrm{Sm}) / \mathrm{Mn}$. Rare earth elements were normalized to average chondrite values [32].

\section{Results}

3.1. Machine-Learned Model for Distinguishing Four Prominent Ordovician K-Bentonites Based on EPMA data

3.1.1. Model Results for the UMV-Model

We built the UMV-model based on the Emerson et al. [15] dataset (Figure 3).

\subsubsection{Cross-Validation of the UMV-Model Using the Carey Dataset}

The UMV-model has distinct differences in identifying the Deicke and Millbrig Kbentonite correctly (Table 2; Figure 3). We treated the data from the known Deicke and Millbrig K-bentonite locations of Carey et al. [14] as unknowns to test the UMV-model. The Deicke K-bentonite was much more reliably identified than the Millbrig K-bentonite. In particular, cut-off values of $\mathrm{Cl}$ concentrations and $\mathrm{Mg} / \mathrm{Mn}$ ratios led to misidentification on the fringes of individual data clusters (Figure 4). 
Table 2. Cross-validation results of UMV-model using the Carey et al. [14] dataset. Columns indicate the percentage of identification based on model.

\begin{tabular}{ccccc}
\hline $\begin{array}{c}\text { K-Bentonite Identified by } \\
\text { Carey et al. [14] }\end{array}$ & Deicke & Millbrig & Elkport & Dickeyville \\
\hline Deicke $(\mathrm{n}=405)$ & $94.6 \%$ & $2.2 \%$ & $1.0 \%$ & $2.2 \%$ \\
Millbrig $(\mathrm{n}=438)$ & $3.2 \%$ & $84.0 \%$ & $3.9 \%$ & $8.9 \%$ \\
\hline
\end{tabular}

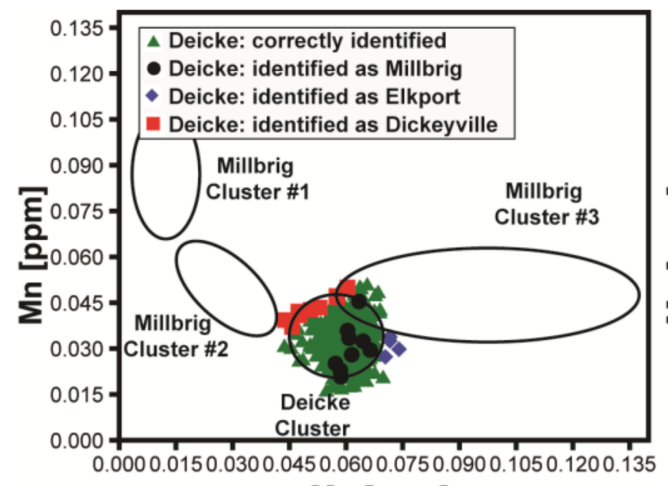

Mg [ppm]

(a)

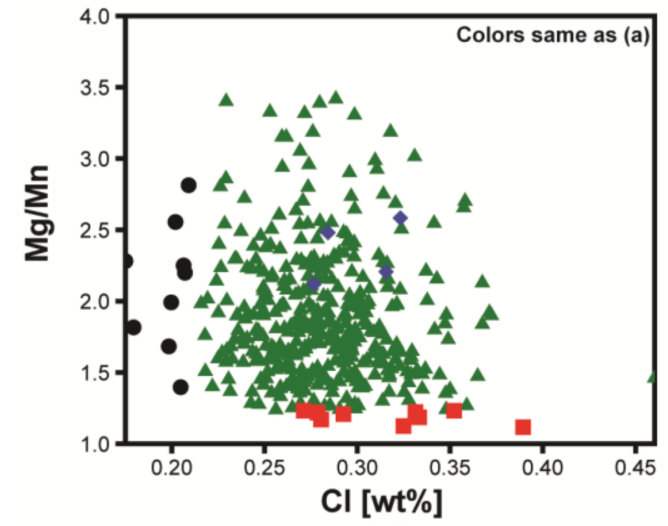

(b)

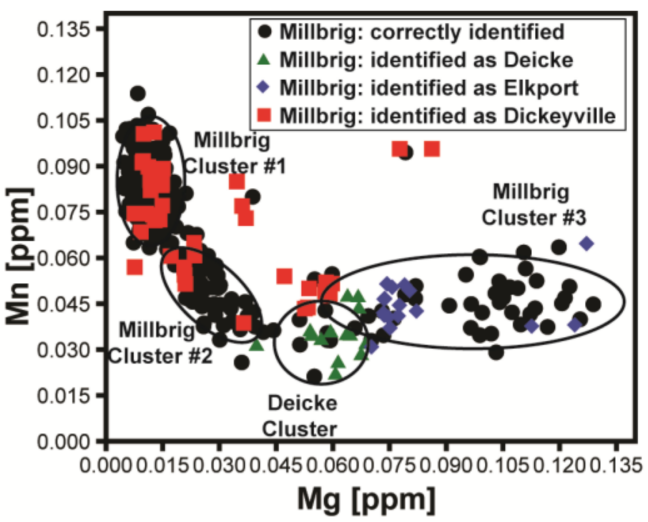

(c)

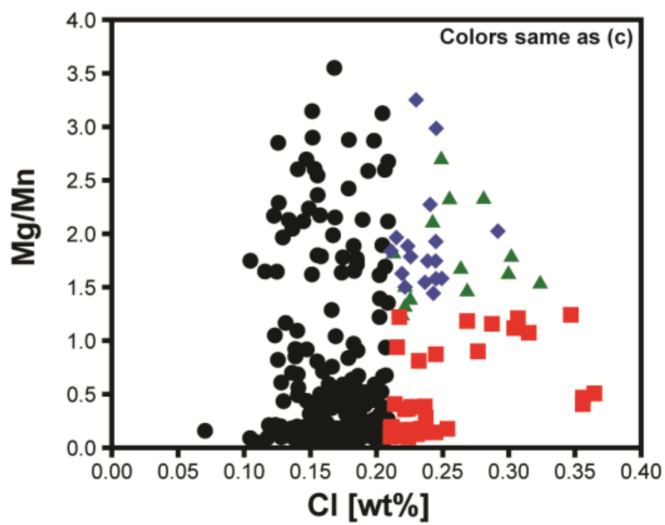

(d)

Figure 4. Identification of misidentified Deicke and Millbrig samples from the dataset of Carey et al. [14] using the dataset of Emerson et al. [15] as the training dataset. (a) Clustering of Deicke samples in Mg-Mn space; (b) Clustering of Deicke samples in $\mathrm{Cl}-\mathrm{Mg} / \mathrm{Mn}$ space. (c) Clustering of Millbrig samples in Mg-Mn space; (d) Clustering of Millbrig samples in $\mathrm{Cl}-\mathrm{Mg} / \mathrm{Mn}$ space. The misidentifications are due to offsets in $\mathrm{Cl}, \mathrm{Mn}$, and $\mathrm{Mg}$ concentrations were chosen by the $\mathrm{ML}$ algorithm as cut-offs. In particular the $\mathrm{Cl}$ concentration cut-off at 0.21 leads to the most misidentified Millbrig as well as misidentified Deicke samples. The Millbrig and Deicke clusters shown in (a,c) are from Carey et al. [14]. $\mathrm{Mn}$ and $\mathrm{Mg}$ concentrations are in PPM and $\mathrm{Cl}$ concentration is in weight \%.

\subsection{Machine-Learned Model for Distinguishing Ordovician K-Bentonites Based on LA-ICP-MS} Data from Big Ridge, $A L$

3.2.1. Cross-Validation of the LA-ICP-MS-Model using the Known K-Bentonites from the Upper Mississippi Valley

There is no available LA-ICP-MS dataset that can be used for cross-validation similar to the cross-validation of the UMV-model. Although Sell et al. [5] analyzed apatite phenocrysts from K-bentonites using LA-ICP-MS, the available dataset that is part of the supplementary online material accompanying that 2015 paper unfortunately lacks data for critical elements (e.g., Mg) that were reported by the authors to have been obtained from analyses of several specific K-bentonite samples that are of interest herein, thus preventing us from making a meaningful comparison. Therefore, we analyzed a subset of the apatite 
phenocrysts from well-known K-bentonites in the UMV (Figure 1) that are equivalent to the samples published by Emerson et al. [15]. The results are shown in Figures 5 and 6, and these new data are available in online Appendix B.

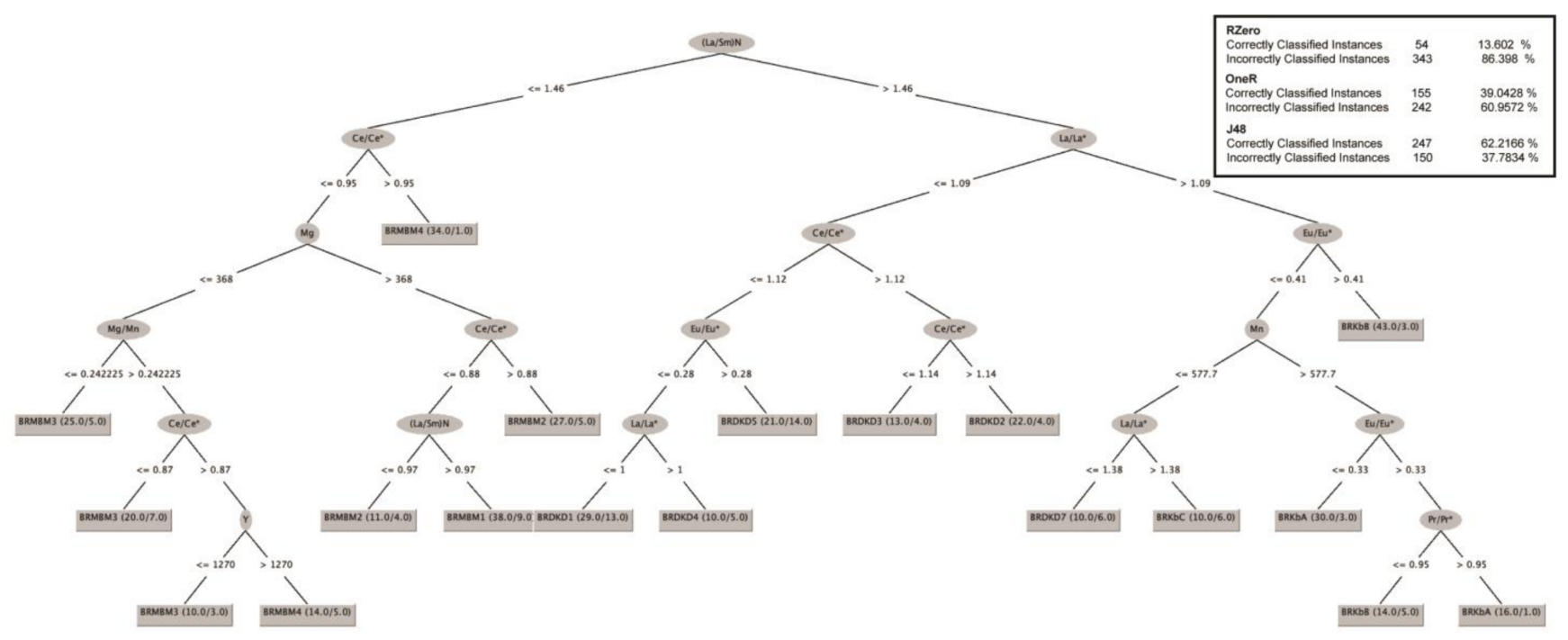

Figure 5. Big-Ridge-Model decision tree of five Ordovician K-bentonites exposed in outcrop at Big Ridge using the J48 classifier. Shown in the inset are the percentages for correctly and incorrectly classified instances based on different decision modes. RZero: essentially guessing the most abundant class for every instance; OneR: classifying each instance based on only one variable.

The Deicke K-bentonite samples from Minnesota (St. Paul and Rochester locations), and Iowa (Decorah location) are identified by the model. Only the sample from Decorah includes predictions that are not originating from one of the Deicke horizons at Big Ridge. The majority of instances in the samples from St. Paul and Rochester appear to come from horizon D5. At Decorah, the majority of instances are consistent with horizon D7 at Big Ridge. The minority of samples have an affinity with the lower horizons of the Deicke at Big Ridge (D1-D4).

The Millbrig K-bentonite samples from the St. Paul and Rochester sections are identified by the model. The majority of instances in those two samples appear to come from horizons M3 and M4. The minority of samples have an affinity with the lower horizons of the Millbrig at Big Ridge (M1-M2). Only one misidentified sample occurs in the Rochester sample.

The Elkport K-bentonite sample from the Dickeyville, WI section has a majority of $\mathrm{Kb}$-B affinity, however it also has several instances from all other K-bentonites at Big Ridge.

3.2.2. Identification of Unknown K-Bentonites in the Southern Appalachians Using the Big-Ridge-Model

The two K-bentonite samples from the Tidwell Hollow location have clear differences. Sample "TH 'Millbrig'" has a majority of Millbrig horizons identified (M2-M4), while Sample "TH 'Deicke" has a majority of Deicke horizons identified (D1-D7). Besides Deicke horizons, there were no misidentified horizons in that sample, but the TH 'Millbrig' did have a minor contribution of samples that were identified as Deicke samples.

The "Fort Payne 'Deicke" K-bentonite samples include only predictions that are originating from different Deicke horizons at Big Ridge. The majority of instances come from horizon D5 and D1, with a minor contribution from D4.

The "Bruton Gap" K-bentonite samples include a mix of predictions that are originating from different Deicke horizons (D1 and D4) and one Millbrig horizon (M4) at Big Ridge. The majority of instances come from the Millbrig horizon. 


\section{Known Deicke K-bentonites}
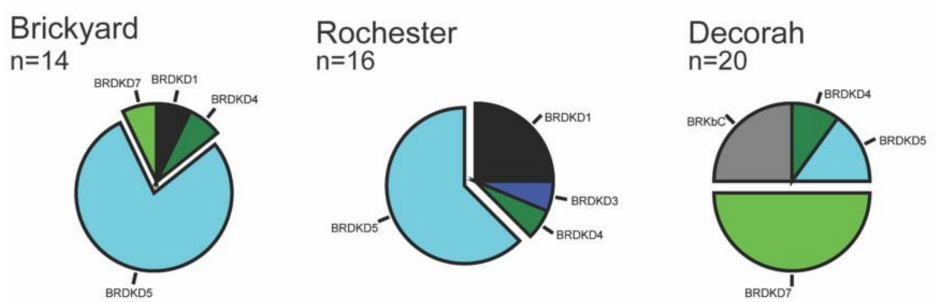

Known Millbrig and Elkport K-bentonites

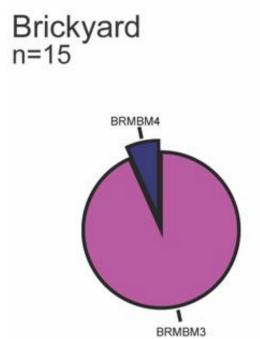

Rochester
$\mathrm{n}=36$

$\underset{\mathrm{n}=18}{\text { Dickeyville, Elkport }}$
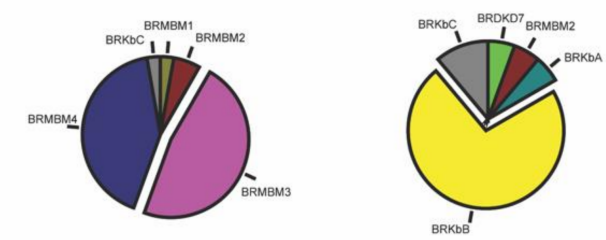

Previously unknown but suspected Deicke and Millbrig K-bentonites
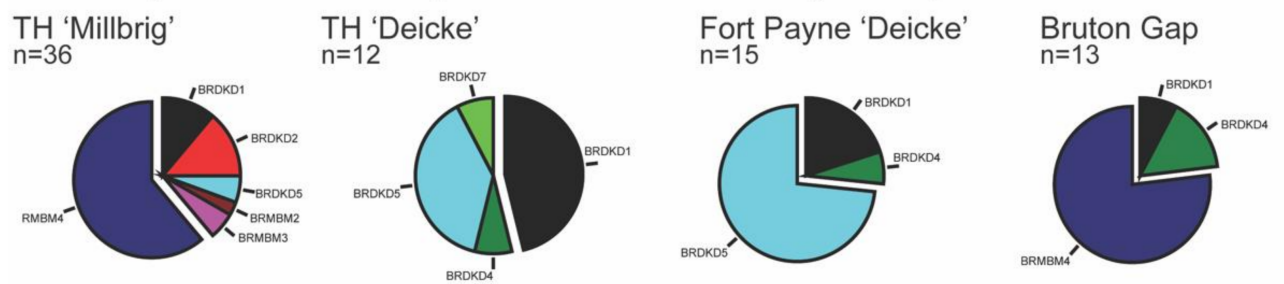

Figure 6. Identification results based on applying the Big-Ridge-Model to K-bentonite beds that had previously been identified as Deicke, Millbrig, and Elkport K-bentonites in the Upper Mississippi Valley and K-bentonite beds in the Southern Appalachians that had previously been interpreted as correlative to the K-bentonites in the Upper Mississippi Valley. 'Brickyard' is the informal field name of the exposure where the Deicke K-bentonite sample was collected in St. Paul, Minnesota; 'TH' is Tidwell Hollow, Alabama.

\section{Discussion}

\subsection{Evaluation of the ML Models Based on Geochemical Data of Apatite Phenocrysts}

The main elements that the UMV-model chooses are based on elemental concentration patterns of $\mathrm{Mg}, \mathrm{Mn}$, and $\mathrm{Cl}$. This is consistent with previous suggestions that these three elements are important for distinguishing Ordovician K-bentonites [14]. Nevertheless, the different models lead to misidentifications for the following reasons.

First, different experimental setups for the analysis can lead to offsets in absolute values of the different elements. This has been shown to be an issue for Ordovician $\mathrm{K}$-bentonites before [5,27]. In particular, problems of accurately quantifying $\mathrm{Cl}$ and $\mathrm{F}$ concentrations in geological samples, including apatites, using EPMA has been well documented $[33,34]$. Thus, offsets of data points and data point clusters caused by analytical differences can have a significant impact on the correct identification and correlation of individual K-bentonite beds.

Second, the heterogeneity of individual K-bentonites that consist of multiple tephra layers produced by different eruptions, or by different phases of the same eruption, can create problems for the correct identification of a given K-bentonite bed. The algorithm works best if discrete clusters of unique elemental concentration pairs can be found. The J48 classifier used in WEKA, which is based on the C4.5 classifier [26], is an algorithm that aims at choosing the particular attribute of the data which most effectively splits its set of samples into subsets at each node of the decision tree. At least two of the Ordovician K-bentonites, however, have been shown to be the result of multiple eruption phases that 
led to distinct changes in the geochemistry of the phenocrysts of each eruptive phase. For example, on the basis of textural changes in a key exposure in Tennessee, Haynes [30] hypothesized that the Millbrig K-bentonite might consist of four individual ash falls, each with distinct lithological characteristics. This interpretation is consistent with the identification of temporal geochemical changes during the deposition of each ash layer as identified by unique clusters (Figure 3; see refs. [5,14]). More recently, Herrmann et al. [27] showed that the Deicke K-bentonite also has multiple layers, and they suggest that this finding can most likely be attributed to the amalgamation of several discrete tephra layers into one stratigraphic horizon as seen today. The type localities and type sections of the Deicke and Millbrig K-bentonites are in the Upper Mississippi Valley (UMV) and are relatively far removed from the Ordovician volcanic centers that produced these ash falls. Additionally, because the K-bentonites are much thinner in the UMV (maximum of several $\mathrm{cm}$ thick) than they are exposures that are closer to the volcanic centers, like the Big Ridge section (Figure 2) in Alabama (up to $1.2 \mathrm{~m}$ thick; $[27,29]_{-}$, it is conceivable that not all ash fall layers will have all known clusters represented in the more distal locations.

Third, the depositional environments along the active margin of Eastern Laurentia during the eruption of the volcano(es) responsible for producing the tephras that comprise the Hagan K-bentonite complex were highly dynamic. Locally and regionally, these include carbonate platform environments, mixed siliciclastic and carbonate environments, and strictly siliciclastic environments, all of which having been interpreted as being in relatively shallow water setting with currents that probably led to the resuspension, erosion and redeposition of the tephras that could have led to mixing of individual tephra components in what are now the K-bentonite beds of this region [21,29,30,35].

Lastly, closer to the eruption center, it would be expected that the largest phenocrysts will have been deposited. In the case of the Deicke K-bentonite, Herrmann et al. [27] also showed that significant zonation is present within apatite phenocrysts. Thus, magma evolution during the eruption can lead to geochemical zonation within individual apatite grains that at the small spot size of EPMA can lead to noise within the dataset. The generally larger spot size of LA-ICP-MS analyses tend to average these values.

\subsection{Identification of Unknown K-Bentonites}

\subsubsection{Identification and Correlation of "K-Bentonite B" at Big Ridge}

The ML model using LA-ICP-MS data was able to establish a link between a previously unnamed K-bentonite at Big Ridge (field notation K-b B; Figure 1) with the Elkport Kbentonite of the Upper Mississippi Valley. The stratigraphic location of K-b B above the Millbrig is consistent with the relative stratigraphic positions of the Millbrig and Elkport K-bentonites in the Upper Mississippi Valley. Thus, we tentatively assign K-b B as the Elkport K-bentonite, with high confidence. This allows a high-resolution correlation of K-bentonites in Alabama to be expanded from only the Deicke and Millbrig stratigraphic interval, to the younger Elkport level. This is an important finding, one that is critical to establishing an ever-more precise correlation framework for evaluating environmental changes across this interval $[20,21]$.

4.2.2. Identification and Correlation of the Deicke and Millbrig K-Bentonites at Tidwell Hollow and Fort Payne

The ML model using LA-ICP-MS data was able to confirm the previous interpretation that the Deicke and Millbrig K-bentonites are present at Tidwell Hollow [29] and that the Deicke is present at Fort Payne $[20,29,30]$. Confirming the presence of these K-bentonites at Tidwell Hollow is not only important for constraining the timing of environmental changes across this interval $[20,21]$, but also for interpreting the paleogeographic and environmental setting of this area during the later Ordovician. The observation that, despite the small dataset, essentially all Deicke and Millbrig horizons from Big Ridge can be identified at these locations, attests to the closeness to the volcanic center such that effectively no filtering of the tephra through depositional processes occurred. 


\subsubsection{Identification and Correlation of the Millbrig K-Bentonites at Bruton Gap}

The ML model tentatively assigns the unknown K-bentonite from Bruton Gap, Alabama to the Millbrig. This unknown K-bentonite is one of five K-bentonites identified in the Bruton Gap section by Haynes [30], in particular this bed is a relatively thin K-bentonite bed that was collected upsection from the thicker K-bentonite tentatively identified as the Deicke, and downsection from the thicker biotite-rich K-bentonite tentatively identified as the Millbrig. With identification of this thinner K-bentonite as having Millbrig affinity, it is quite possible that the original stratigraphic "picks" of Haynes [30] for the Bruton Gap section should be re-evaluated and compared not with the Big Ridge section to the northeast, but with the Red Mountain Expressway section to the southwest, where lenses and discontinuous beds of limestone are intercalated with the Millbrig K-bentonite, as now seems to be the better explanation for the K-bentonite stratigraphy at Bruton Gap. Additional work is planned for further investigation of the Bruton Gap section and its precise relationships with the other sections in the region.

4.2.4. Fine-Tuning our Understanding of the Eruptive Sequence of Ordovician K-Bentonites Generated by Large Caldera Building Eruptions

At the Big Ridge section (Figure 2) the Deicke and Millbrig K-bentonites are of relatively great thickness [35], and those exposures can be confidently assumed to represent proximal, coarse-grained archives for the eruption of tephras generated during caldera building events. The Deicke and Millbrig K-bentonites at Big Ridge both reach 1-1.2 $\mathrm{m}$ in thickness, and both beds can be subdivided into individual layers based on lithological and mineralogical observations (Figure 2). In contrast, in the Upper Mississippi Valley, where the stratotypes for many of the prominent Ordovician K-bentonites are located [36], the altered tephras are commonly only a few $\mathrm{cm}$ thick at most. The majority of the Deicke and Millbrig apatite phenocrysts from UMV samples appear to have originated during the later stages of the formation of the tephra precursors that have now altered to K-bentonites. The samples from the Deicke in the UMV are dominated by horizons D5 and D7, whereas the Millbrig samples from the UMV are dominated by horizons M3 and M4. Thus, it appears that the first eruption events were smaller in scale, and the caldera forming, massive events happened at the end of each eruption. This would be consistent with previous observations of K-bentonite samples from Virginia [14] that showed changes in the eruptive sequence. Here, based on the absence of apatite phenocrysts that would be the more distal Upper Mississippi Valley time equivalents with the early stages of volcanism as documented at the more proximal Big Ridge section, we can also document that the eruptive style of the of the explosive eruptions' later stages led to a wider dispersal of the volcanic ash. Therefore, we conclude that in samples from more distal locations relative to these volcanic centers, tephra from the early stages might be missing.

\section{Conclusions}

We have demonstrated how ML can be applied to a stratigraphic problem with measurable success. Using apatite phenocryst geochemical data from several Ordovician K-bentonite beds, including the well-known Deicke and Millbrig K-bentonites, which are layers of altered airfall tephra from explosive volcanic eruptions at $454-455 \mathrm{Ma}$ along the Laurentian margin, ML methodology separates and distinguishes the phenocrysts in a given K-bentonite from those in others, and our results show the value of ML in chronostratigraphy and tephrostratigraphy. Our results are also in accord with prior studies which suggested that both the Millbrig and the Deicke explosively eruptive events consisted of multiple eruptive stages. We establish with confidence that only the phenocrysts from the later stages of the eruption were deposited in the more distal regions that now comprise the many excellent exposures in the Upper Mississippi Valley, as compared with the more complete record of phenocrysts that are present in the more proximal sections of Alabama.

The Elkport K-bentonite is for the first time identified in the Big Ridge outcrop. This finding now allows for correlation of the Upper Mississippi Valley deposits into Alabama 
at this chronostratigraphically precise horizon. The presence of the Deicke and Millbrig K-bentonites at Tidwell Hollow, Alabama, is confirmed. An unknown K-bentonite at Bruton Gap, Alabama, is tentatively assigned to the Millbrig, but further work is planned to confirm its position within the Bruton Gap sequence and to refine its usefulness for regional correlation.

Future work is needed to establish elemental profiles that can best be used to characterize individual K-bentonite beds based on geochemical fingerprinting. This might include elements that are not frequently analyzed in apatites so far. Finally, we note that care must be taken if samples for the training set are collected from exposures that are relatively far away from the eruption center, as such samples from a more distant location might very well not be representative of the entire eruptive sequence.

Author Contributions: Conceptualization, A.D.H. and J.T.H.; methodology, A.D.H.; J.T.H., R.M.R., N.R.E.; fieldwork and sampling, A.D.H., N.R.E., R.M.R., J.T.H.; software, A.D.H.; validation, A.D.H.; writing—original draft preparation, A.D.H., J.T.H.; data analysis and interpretation, A.D.H., J.T.H., R.M.R., N.R.E.; writing-review and editing, A.D.H., J.T.H., R.M.R., N.R.E.; funding acquisition, A.D.H. All authors have read and agreed to the published version of the manuscript.

Funding: A.D.H. acknowledges funding from the National Science Foundation (EAR-1324954). RMR thanks GEODE funding (BG-004172) from the Department of Geology and Geophysics at LSU. Part of this work is part of RMR's dissertation project at LSU, specifically LA-ICP-MS work to identify the geochemistry of apatite from K-bentonite beds.

Institutional Review Board Statement: Not applicable.

Informed Consent Statement: Not applicable.

Data Availability Statement: The data for this paper is available in the Appendices A and B.

Acknowledgments: We thank the two anonymous reviewers whose comments/suggestions helped improve and clarify this manuscript.

Conflicts of Interest: The authors declare no conflict of interest. The funders had no role in the design of the study; in the collection, analyses, or interpretation of data; in the writing of the manuscript, or in the decision to publish the results. 


\section{Appendix A}

LA-ICP-MS results of known Ordovician K-bentonites used for the ML training set.

Table A1. Results from the LA-ICP-MS analyses used as the training set. All elemental abundances are given in ppm.

\begin{tabular}{|c|c|c|c|c|c|c|c|c|c|c|c|c|c|c|c|c|c|c|c|c|}
\hline Sample Name & $\mathrm{Mg}$ & Mn & $\mathrm{Fe}$ & $\mathbf{Y}$ & Th & $\mathbf{U}$ & $\mathbf{L a}$ & $\mathrm{Ce}$ & Pr & Nd & $\mathrm{Sm}$ & $\mathbf{E u}$ & Gd & $\mathrm{Tb}$ & Dy & Ho & Er & Tm & $\mathrm{Yb}$ & Lu \\
\hline Big_Ridge_M1_1 & 1009 & 859 & 1079 & 1599 & 8.78 & 2.37 & 542 & 1326 & 225 & 1210 & 298 & 14.8 & 320 & 42.9 & 252 & 46.4 & 115.1 & 13.29 & 71.3 & 9.09 \\
\hline Big_Ridge_M1_2 & 836 & 757 & 842 & 1400 & 15.44 & 4.7 & 741 & 1782 & 297 & 1620 & 395 & 22.2 & 400 & 56.1 & 316 & 57.7 & 141.6 & 15.85 & 80.5 & 10.47 \\
\hline Big_Ridge_M1_3 & 1125 & 570 & 757 & 1409 & 16.5 & 3.75 & 689 & 1677 & 287 & 1563 & 386 & 23.2 & 386 & 54.3 & 309 & 58.4 & 144.2 & 16.46 & 83.6 & 11.13 \\
\hline Big_Ridge_M1_5 & 1000 & 566 & 748 & 926 & 20.2 & 4.1 & 715 & 1822 & 296 & 1542 & 339 & 23.1 & 328 & 42.7 & 234 & 42.6 & 104.3 & 11.66 & 60.2 & 8.38 \\
\hline Big_Ridge_M1_6 & 817 & 570 & 725 & 1317 & 13.85 & 3.75 & 699 & 1746 & 301 & 1623 & 383 & 24.3 & 382 & 51.7 & 294 & 55.1 & 138.5 & 16.09 & 83.6 & 10.78 \\
\hline Big_Ridge_M1_7 & 1270 & 623 & 855 & 1653 & 20.3 & 10.66 & 824 & 2140 & 369 & 1992 & 509 & 24.3 & 502 & 68.5 & 391 & 71.2 & 174 & 19.6 & 99 & 12.76 \\
\hline Big_Ridge_M1_8 & 574 & 697 & 576 & 1493 & 29.9 & 4.51 & 869 & 2130 & 358 & 1920 & 452 & 28 & 429 & 57 & 321 & 57.9 & 146.2 & 16.6 & 85.9 & 11.49 \\
\hline Big_Ridge_M1_10 & 1014 & 596 & 812 & 1398 & 21.8 & 4.53 & 788 & 1967 & 340 & 1830 & 437 & 23.9 & 420 & 55.8 & 314 & 57.5 & 140.5 & 16.5 & 84.7 & 10.84 \\
\hline Big_Ridge_M1_11 & 842 & 665 & 817 & 1162 & 12.96 & 4.27 & 783 & 1892 & 316 & 1655 & 373 & 23.4 & 363 & 48.7 & 273 & 49.6 & 118.6 & 13.63 & 70.7 & 9.14 \\
\hline Big_Ridge_M1_12 & 1142 & 815 & 1081 & 1766 & 27.5 & 3.95 & 869 & 2095 & 365 & 2017 & 477 & 24.56 & 468 & 63.2 & 377 & 74.8 & 204.2 & 25.5 & 138.8 & 18.79 \\
\hline Big_Ridge_M1_13 & 396 & 614 & 574 & 1669 & 26.5 & 3.93 & 932 & 2289 & 385 & 2116 & 508 & 29 & 502 & 66.8 & 374 & 67 & 164.9 & 18.36 & 93.1 & 11.84 \\
\hline Big_Ridge_M1_14 & 916 & 689 & 841 & 1641 & 15.97 & 5.85 & 807 & 1915 & 329 & 1744 & 438 & 21.8 & 460 & 64.8 & 369 & 68.7 & 167.3 & 18.12 & 91 & 11.83 \\
\hline Big_Ridge_M1_15 & 447 & 577.7 & 613 & 2162 & 105.1 & 23.4 & 1276 & 3030 & 507 & 2760 & 649 & 37 & 636 & 85.6 & 474 & 85 & 207.8 & 23.8 & 120.2 & 15.8 \\
\hline Big_Ridge_M1_16 & 994 & 753 & 1006 & 2099 & 11.68 & 7.75 & 659 & 1743 & 308 & 1730 & 486 & 21.25 & 537 & 78.5 & 463 & 88.5 & 218.9 & 24.9 & 124.2 & 16.47 \\
\hline Big_Ridge_M1_17 & 273 & 764 & 509 & 1867 & 31.9 & 4.08 & 539 & 1427 & 265.8 & 1544 & 454 & 26.31 & 490 & 69.5 & 405 & 74.8 & 185 & 21.3 & 109.2 & 14.14 \\
\hline Big_Ridge_M1_18 & 838 & 710 & 859 & 2630 & 39.1 & 8.99 & 997 & 2485 & 431 & 2320 & 618 & 27.2 & 662 & 99.3 & 585 & 110.3 & 273 & 30.5 & 153.7 & 19.5 \\
\hline Big_Ridge_M1_20 & 1110 & 580 & 822 & 1415 & 22 & 4.39 & 745 & 1822 & 316 & 1720 & 416 & 27.8 & 412 & 55.5 & 318 & 58.7 & 145.2 & 16.5 & 85.3 & 11.05 \\
\hline Big_Ridge_M1_21 & 862 & 528 & 737 & 1599 & 17.6 & 8.33 & 717 & 1778 & 315 & 1721 & 450 & 23.9 & 475 & 67.2 & 395 & 72.3 & 177 & 19.5 & 94.2 & 12.34 \\
\hline Big_Ridge_M1_22 & 1193 & 548 & 807 & 1283 & 17.1 & 4.28 & 775 & 1796 & 307 & 1697 & 390 & 23.6 & 378 & 50.3 & 278 & 49.4 & 123.4 & 14.1 & 70.1 & 9.17 \\
\hline Big_Ridge_M1_23 & 928 & 502 & 742 & 1468 & 23.3 & 4.84 & 793 & 1897 & 328 & 1810 & 436 & 26.5 & 435 & 59.1 & 325 & 57 & 140.4 & 16.2 & 82.5 & 10.75 \\
\hline Big_Ridge_M1_24 & 752 & 695 & 797 & 1486 & 21.8 & 4.65 & 691 & 1820 & 317.7 & 1757 & 460 & 22.78 & 452 & 62 & 353 & 63.6 & 157.7 & 17.51 & 89.3 & 11.75 \\
\hline Big_Ridge_M1_25 & 824 & 690 & 816 & 1490 & 19.7 & 5.29 & 821 & 2029 & 339 & 1818 & 434 & 25.6 & 427 & 58.8 & 334 & 60.9 & 150.3 & 16.94 & 87 & 11.28 \\
\hline Big_Ridge_M1_26 & 309 & 554 & 613 & 1319 & 14.1 & 3.7 & 743 & 1840 & 302 & 1549 & 373 & 26.3 & 385 & 52.3 & 295 & 54.7 & 134.3 & 14.99 & 74.5 & 9.62 \\
\hline Big_Ridge_M1_27 & 188 & 763 & 449 & 1888 & 37.5 & 6.39 & 545 & 1435 & 269.3 & 1584 & 473 & 27.6 & 505 & 72.7 & 416 & 76.2 & 188.2 & 21.67 & 109.3 & 14.04 \\
\hline Big_Ridge_M1_28 & 230 & 762 & 480 & 1383 & 19.2 & 3.33 & 439 & 1271 & 226 & 1228 & 344 & 20 & 353 & 50.3 & 292 & 52.7 & 132 & 15.1 & 81.2 & 10.67 \\
\hline Big_Ridge_M1_29 & 374 & 748 & 630 & 1263 & 23.8 & 4.7 & 812 & 2070 & 334 & 1677 & 368 & 23.6 & 336 & 45.3 & 250 & 46.2 & 121.5 & 14.95 & 81.6 & 11.26 \\
\hline Big_Ridge_M1_30 & 908 & 681 & 840 & 1657 & 13.47 & 4.93 & 761 & 1792 & 305.3 & 1662 & 428 & 19.71 & 454 & 65.3 & 377 & 68.7 & 168.7 & 18.58 & 91.9 & 11.95 \\
\hline Big_Ridge_M1_31 & 1061 & 819 & 1080 & 1450 & 14.2 & 4.35 & 665 & 1760 & 305 & 1610 & 407 & 21.1 & 417 & 59 & 330 & 58.5 & 146 & 17.6 & 90.6 & 11.6 \\
\hline Big_Ridge_M1_32 & 822 & 694 & 816 & 1376 & 11.8 & 4.85 & 674 & 1712 & 291 & 1552 & 386 & 21.7 & 388 & 54.1 & 315 & 57.6 & 140.8 & 15.66 & 77.9 & 10.16 \\
\hline Big_Ridge_M1_33 & 769 & 677 & 803 & 541 & 18.4 & 5.14 & 666 & 1526 & 226 & 1022 & 182 & 23.4 & 154.2 & 19 & 97.7 & 17.4 & 47.1 & 5.76 & 31.5 & 4.57 \\
\hline
\end{tabular}


Table A1. Cont.

\begin{tabular}{|c|c|c|c|c|c|c|c|c|c|c|c|c|c|c|c|c|c|c|c|c|}
\hline Sample Name & Mg & Mn & $\mathrm{Fe}$ & $\mathbf{Y}$ & Th & $\mathbf{U}$ & La & $\mathrm{Ce}$ & Pr & Nd & Sm & Eu & Gd & $\mathrm{Tb}$ & Dy & Ho & Er & $\mathrm{Tm}$ & $\mathrm{Yb}$ & Lu \\
\hline Big_Ridge_M1_34 & 961 & 730 & 893 & 1255 & 13.7 & 3.43 & 706 & 1780 & 304 & 1620 & 388 & 23.2 & 384 & 50.8 & 283 & 51.2 & 126.3 & 13.9 & 69.3 & 9.27 \\
\hline Big_Ridge_M1_35 & 853 & 667 & 821 & 1798 & 21.3 & 8.75 & 796 & 1942 & 350 & 1917 & 490 & 24.8 & 488 & 68.5 & 399 & 74 & 186 & 20.9 & 106.8 & 13.52 \\
\hline Big_Ridge_M1_36 & 1070 & 768 & 582 & 1450 & 15 & 3.41 & 444 & 1200 & 225 & 1273 & 376 & 21.9 & 397 & 57.7 & 324 & 60.5 & 152 & 17 & 85 & 10.67 \\
\hline Big_Ridge_M1_38 & 1059 & 615 & 959 & 1765 & 57.3 & 16.3 & 925 & 2310 & 396 & 2120 & 518 & 25.4 & 505 & 70.3 & 413 & 73.8 & 187 & 22.2 & 118 & 16.6 \\
\hline Big_Ridge_M1_39 & 188 & 741 & 430 & 1376 & 19.1 & 2.98 & 509 & 1310 & 238 & 1321 & 354 & 20.8 & 356 & 50.2 & 296 & 53.4 & 133.6 & 15.2 & 81.6 & 10.64 \\
\hline Big_Ridge_M1_40 & 830 & 892 & 1019 & 2052 & 19.67 & 5.33 & 656 & 1657 & 301.2 & 1683 & 464 & 23.37 & 484 & 72.1 & 425 & 79.7 & 205.2 & 23.98 & 123.9 & 16.39 \\
\hline Big_Ridge_M1_41 & 774.2 & 650 & 795 & 1337 & 18.46 & 4.59 & 774 & 1786 & 309.7 & 1701 & 398 & 22.21 & 388 & 52.4 & 295.9 & 54 & 137 & 15.56 & 80.5 & 10.39 \\
\hline Big_Ridge_M2_2 & 1160 & 1028 & 1419 & 1853 & 18 & 8.53 & 519 & 1487 & 263.1 & 1424 & 419 & 20.54 & 460 & 70.1 & 416 & 75.8 & 196.8 & 24 & 117 & 15.08 \\
\hline Big_Ridge_M2_3 & 508 & 831 & 820 & 1245 & 14.76 & 3.6 & 509 & 1407 & 248.1 & 1302 & 350 & 20.48 & 342 & 49.2 & 277 & 48 & 122.8 & 14.72 & 73.3 & 9.6 \\
\hline Big_Ridge_M2_4 & 998 & 508 & 973 & 1112 & 21.2 & 4.28 & 742 & 1695 & 292.3 & 1628 & 369 & 26.49 & 357 & 46.4 & 253.8 & 45.4 & 116.1 & 13.6 & 67.9 & 9.32 \\
\hline Big_Ridge_M2_5 & 990 & 915 & 1248 & 1843 & 11.69 & 5.5 & 486 & 1456 & 245 & 1306 & 376 & 17.49 & 414 & 65.3 & 391 & 72 & 191 & 23.2 & 116.5 & 15.2 \\
\hline Big_Ridge_M2_6 & 782 & 792 & 1086 & 1720 & 13.2 & 4.75 & 533 & 1496 & 263 & 1392 & 384 & 18.2 & 411 & 61.3 & 354 & 65.2 & 172 & 20.5 & 99 & 13.03 \\
\hline Big_Ridge_M2_7 & 1160 & 694 & 656 & 1386 & 25.1 & 3.22 & 477 & 1226 & 219 & 1245 & 346 & 20.9 & 350 & 50.1 & 283 & 51 & 127.7 & 15.28 & 76.1 & 9.91 \\
\hline Big_Ridge_M2_8 & 693 & 550 & 771 & 1358 & 18.9 & 3.34 & 670 & 1669 & 283.1 & 1515 & 383 & 20.59 & 379 & 54 & 298 & 52.2 & 133.9 & 15.49 & 74.7 & 9.79 \\
\hline Big_Ridge_M2_9 & 709 & 459 & 752 & 800 & 14.84 & 4.44 & 714 & 1790 & 280 & 1379 & 282 & 21.99 & 256 & 33.6 & 182 & 31.9 & 81.6 & 9.51 & 47.1 & 6.36 \\
\hline Big_Ridge_M2_10 & 1260 & 508 & 841 & 1002 & 15.1 & 6.22 & 579 & 1622 & 257 & 1249 & 310 & 21.6 & 312 & 43 & 240 & 42 & 105.9 & 11.69 & 57.5 & 7.37 \\
\hline Big_Ridge_M2_12 & 229 & 724 & 477 & 1599 & 16.4 & 3.98 & 525 & 1499 & 264 & 1427 & 409 & & 41 & 60.9 & 34 & 60.8 & 151.3 & 17.88 & 87.7 & 11.36 \\
\hline Big_Ridge_M2_13 & 761 & 636 & 888 & 1637 & 18.33 & 6.98 & 689 & 1839 & 314 & 1685 & 439 & 21.2 & 450 & 64.4 & 373 & 69.1 & 174.4 & 20.64 & 101.9 & 13.51 \\
\hline Big_Ridge_M2_14 & 783 & 640 & 822 & 1048 & 14.9 & 4.02 & 627 & 1573 & 254.4 & 1319 & 315 & 22.1 & 308 & 42.4 & 235 & 42.2 & 105.4 & 12.48 & 61 & 8.09 \\
\hline Big_Ridge_M2_15 & 139.2 & 819 & 438 & 1088 & 10.84 & 1.85 & 373 & 1039 & 182 & 967 & 265 & 15.8 & 276 & 39.3 & 226 & 40.4 & 100.1 & 11.88 & 58 & 7.61 \\
\hline Big_Ridge_M2_16 & 733 & 570 & 869 & 794 & 15.98 & 3.67 & 783 & 1955 & 301 & 1497 & 293 & 21.4 & 256 & 32.5 & 172.1 & 29.7 & 77.7 & 9.23 & 47.4 & 6.54 \\
\hline Big_Ridge_M2_17 & 1165 & 872 & 1395 & 1985 & 10.35 & 4.35 & 493 & 1399 & 246.3 & 1323 & 387 & 17.01 & 428 & 66.8 & 404 & 75.9 & 195 & 23.66 & 117.2 & 15.1 \\
\hline Big_Ridge_M2_18 & 1059 & 823 & 1330 & 1770 & 14.41 & 5.48 & 596 & 1651 & 289 & 1514 & 417 & 19.87 & 434 & 64.3 & 378 & 68.9 & 180.2 & 21.2 & 102.5 & 13.61 \\
\hline Big_Ridge_M2_19 & 766 & 803 & 1046 & 1615 & 13.72 & 6.04 & 676 & 1812 & 309 & 1631 & 415 & 19.12 & 422 & 60.5 & 347 & 63.2 & 160.2 & 18.97 & 94.6 & 12.56 \\
\hline Big_Ridge_M2_20 & 823 & 712 & 1001 & 1462 & 11.19 & 3.65 & 564 & 1563 & 268 & 1433 & 378 & 18.6 & 377 & 54.4 & 321 & 58.6 & 151.7 & 18.2 & 88.4 & 11.43 \\
\hline Big_Ridge_M2_21 & 382 & 931 & 512 & 1018 & 25.4 & 2.89 & 806 & 1866 & 277 & 1282 & 263 & 17.51 & 235.7 & 32.2 & 181.7 & 34.2 & 94.5 & 12.68 & 69.5 & 9.59 \\
\hline Big_Ridge_M2_22 & 991 & 575 & 965 & 1049 & 7.84 & 2.98 & 609 & 1559 & 249.3 & 1326 & 313 & 18.11 & 309 & 42 & 238 & 41.6 & 104.4 & 12.25 & 60.1 & 7.82 \\
\hline Big_Ridge_M2_23 & 1148 & 688 & 1168 & 1759 & 34.8 & 4.31 & 622 & 1603 & 288 & 1637 & 457 & 24.7 & 465 & 68.4 & 398 & 71.6 & 184 & 22.2 & 110.5 & 14.6 \\
\hline Big_Ridge_M2_24 & 1099 & 461.5 & 830 & 613 & 16.6 & 4.25 & 713 & 1739 & 262 & 1222 & 234 & 21.63 & 196.1 & 24.7 & 130.7 & 23.2 & 60 & 7.53 & 40 & 5.51 \\
\hline Big_Ridge_M2_25 & 868 & 939 & 1188 & 2192 & 22.7 & 5.64 & 608 & 1676 & 296.7 & 1638 & 471 & 22.42 & 489 & 74.6 & 450 & 83.9 & 223.4 & 27.6 & 138.3 & 18.43 \\
\hline Big_Ridge_M2_26 & 769 & 787 & 1090 & 1437 & 17.7 & 5.43 & 571 & 1454 & 257 & 1433 & 395 & 18.83 & 396 & 57.1 & 313 & 53.9 & 134.2 & 15.51 & 74.9 & 10.38 \\
\hline Big_Ridge_M2_27 & 690 & 540 & 812 & 902 & 14.38 & 3.77 & 689 & 1624 & 268 & 1376 & 309 & 23.8 & 285 & 37.5 & 204 & 35.2 & 88.4 & 10.35 & 51.4 & 6.88 \\
\hline Big_Ridge_M2_28 & 896 & 483 & 921 & 1166 & 14.53 & 4.1 & 659 & 1670 & 276.4 & 1443 & 357 & 20.31 & 352 & 48.2 & 267.6 & 46.1 & 114.9 & 13.27 & 64.4 & 8.23 \\
\hline Big_Ridge_M2_29 & 704 & 687 & 926 & 1451 & 14.72 & 4.52 & 659 & 1730 & 288 & 1515 & 393 & 21.5 & 388 & 54.4 & 302 & 53.5 & 137.9 & 16.64 & 83.4 & 10.56 \\
\hline
\end{tabular}


Table A1. Cont.

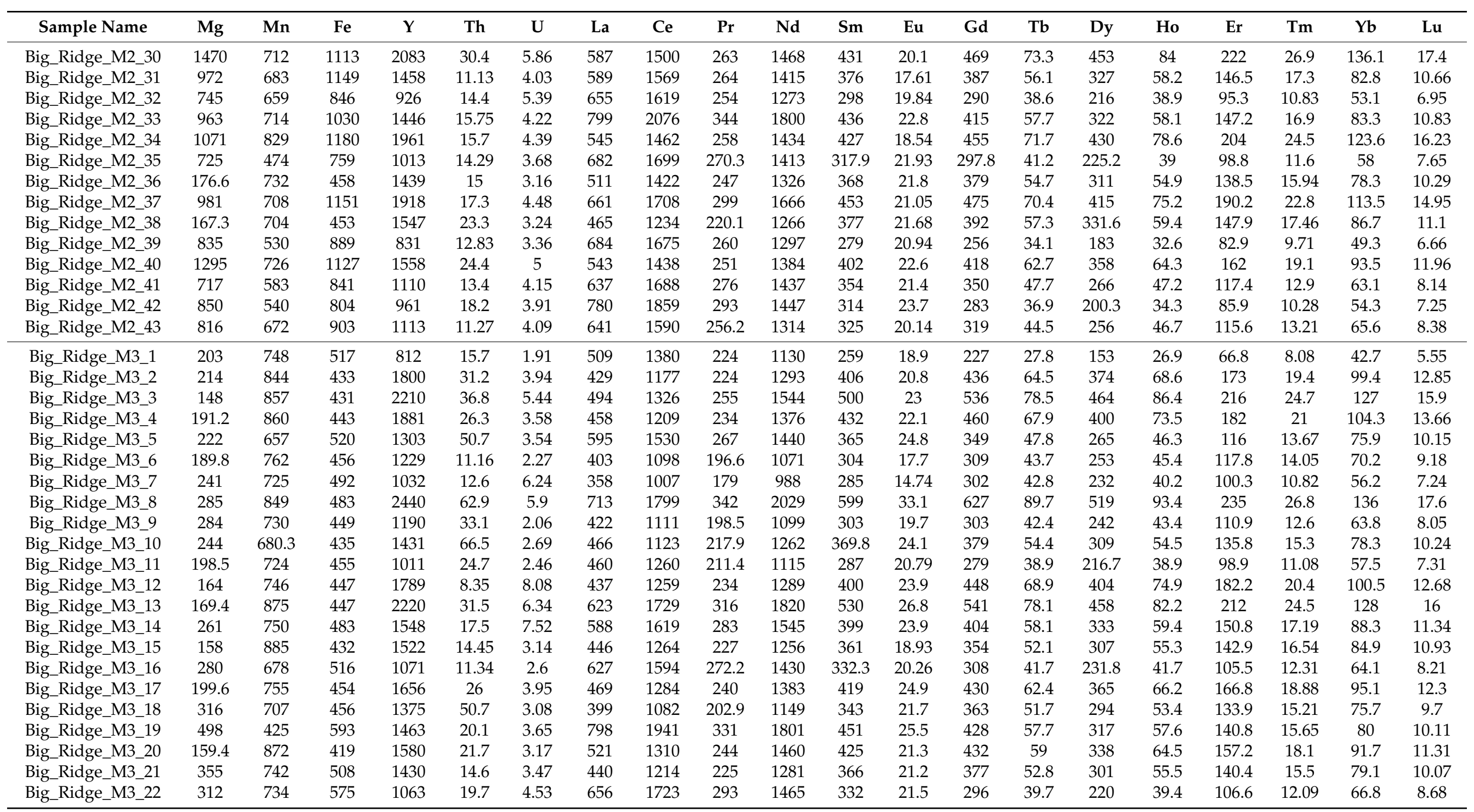


Table A1. Cont.

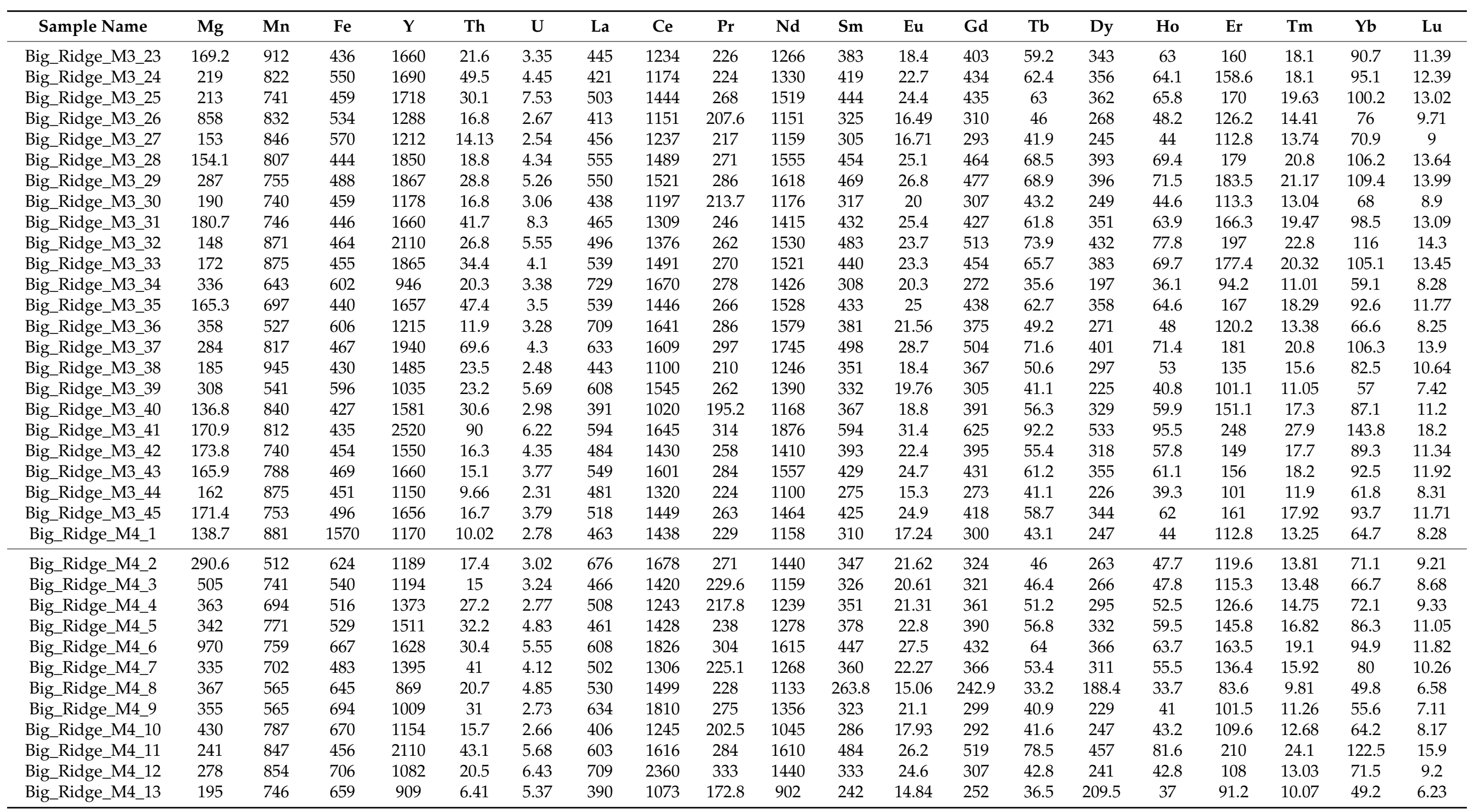


Table A1. Cont.

\begin{tabular}{|c|c|c|c|c|c|c|c|c|c|c|c|c|c|c|c|c|c|c|c|c|}
\hline Sample Name & Mg & Mn & $\mathrm{Fe}$ & $\mathbf{Y}$ & Th & $\mathbf{U}$ & La & $\mathrm{Ce}$ & Pr & Nd & Sm & Eu & Gd & $\mathrm{Tb}$ & Dy & Ho & Er & $\mathrm{Tm}$ & $\mathrm{Yb}$ & Lu \\
\hline Big_Ridge_M4_14 & 368 & 756 & 536 & 747 & 9.5 & 1.77 & 349 & 1112 & 171 & 803 & 209 & 13.5 & 196 & 27.3 & 155 & 28.7 & 71.2 & 8.12 & 41.9 & 5.39 \\
\hline Big_Ridge_M4_15 & 398 & 800 & 537 & 865 & 29.5 & 2.04 & 372 & 1281 & 184 & 927 & 252 & 18.39 & 237 & 33.8 & 191.4 & 32.9 & 81.6 & 9.48 & 46.9 & 5.92 \\
\hline Big_Ridge_M4_16 & 344 & 705 & 515 & 1698 & 23.8 & 3.71 & 478 & 1285 & 226 & 1306 & 410 & 23.3 & 425 & 64.1 & 377 & 68.2 & 167 & 19.1 & 92.2 & 12.37 \\
\hline Big_Ridge_M4_18 & 637 & 831 & 589 & 1220 & 27.3 & 15.5 & 359 & 1220 & 192 & 983 & 292 & 18.7 & 301 & 45.7 & 276 & 50.9 & 127.2 & 14.4 & 74.7 & 9 \\
\hline Big_Ridge_M4_19 & 327 & 608 & 757 & 1369 & 16.9 & 4.54 & 877 & 2780 & 396 & 1830 & 431 & 25.7 & 395 & 57 & 310 & 54.5 & 134.3 & 14.8 & 74 & 9.37 \\
\hline Big_Ridge_M4_20 & 590 & 719 & 536 & 2430 & 61 & 7.2 & 628 & 1704 & 306 & 1800 & 573 & 33.2 & 607 & 91.7 & 523 & 94.4 & 233 & 27.6 & 142 & 18.6 \\
\hline Big_Ridge_M4_21 & 388 & 771 & 622 & 1540 & 48 & 3.4 & 507 & 1640 & 263 & 1370 & 398 & 26.9 & 409 & 60.1 & 343 & 60.3 & 144 & 16.7 & 80.8 & 10.2 \\
\hline Big_Ridge_M4_23 & 381 & 527 & 690 & 1244 & 25.4 & 3.82 & 908 & 2150 & 337 & 1663 & 364 & 22.4 & 328 & 44.7 & 252 & 46.1 & 117.6 & 13.64 & 70.7 & 9.39 \\
\hline Big_Ridge_M4_24 & 319 & 575 & 673 & 1750 & 31.2 & 5.99 & 950 & 2490 & 385 & 1930 & 488 & 29.2 & 514 & 73 & 392 & 73 & 175 & 19.7 & 99 & 13.1 \\
\hline Big_Ridge_M4_25 & 297 & 772 & 548 & 2010 & 45.2 & 8.1 & 615 & 2070 & 334 & 1720 & 511 & 30.7 & 525 & 76.1 & 424 & 75.4 & 189 & 22.3 & 107 & 13.8 \\
\hline Big_Ridge_M4_1 & 241 & 842 & 644 & 631 & 5.75 & 2.17 & 413 & 1390 & 204 & 858 & 188 & 13.6 & 161 & 21.4 & 118.6 & 22.3 & 52.9 & 6.31 & 32 & 4.25 \\
\hline Big_Ridge_M4_2 & 544 & 531 & 804 & 666 & 6.36 & 18.4 & 481 & 1701 & 240.1 & 989 & 218.1 & 15.02 & 212 & 29.2 & 157.1 & 26.3 & 56.9 & 5.94 & 29.1 & 3.62 \\
\hline Big_Ridge_M4_3 & 344 & 870 & 657 & 920 & 17.6 & 1.86 & 425 & 1530 & 223 & 1072 & 254 & 20.7 & 239 & 33.6 & 189 & 36.3 & 83.5 & 9.8 & 50.3 & 6.31 \\
\hline Big_Ridge_M4_4 & 750 & 925 & 716 & 1115 & 37.8 & 3.37 & 483 & 1854 & 287 & 1263 & 310 & 23.3 & 283 & 38.2 & 219 & 39.9 & 97.7 & 11.18 & 60 & 7.48 \\
\hline Big_Ridge_M4_5 & 208.2 & 917 & 624 & 1324 & 13.33 & 3.44 & 521 & 1906 & 294 & 1313 & 327 & 21.59 & 310 & 43.2 & 251.7 & 47 & 115.6 & 13.6 & 71.3 & 9.02 \\
\hline Big_Ridge_M4_6 & 238 & 887 & 586 & 1247 & 15.1 & 3.19 & 461 & 1677 & 263.3 & 1195 & 318 & 21.9 & 308 & 43.4 & 254 & 46.8 & 112.2 & 13.42 & 68.6 & 8.75 \\
\hline Big_Ridge_M4_8 & 275 & 803 & 605 & 960 & 8.72 & 1.332 & 350 & 1119 & 185 & 897 & 232 & 15.98 & 221.1 & 31.1 & 179.7 & 33.6 & 80.6 & 9.57 & 49.5 & 6.35 \\
\hline Big_Ridge_M4_9 & 309 & 822 & 626 & 1240 & 24 & 2.49 & 412 & 1337 & 223 & 1105 & 299 & 21.9 & 309 & 43.9 & 249 & 44.8 & 109.5 & 12.7 & 66.7 & 8.44 \\
\hline Big_Ridge_M4_10 & 364 & 807 & 588 & 2320 & 37.1 & 5.52 & 804 & 2320 & 399 & 2100 & 577 & 36.2 & 554 & 77.2 & 466 & 88.6 & 210 & 25 & 138 & 16.8 \\
\hline Big_Ridge_M4_11 & 230 & 855 & 490 & 1970 & 32.3 & 3.17 & 540 & 1510 & 279 & 1510 & 444 & 23.8 & 463 & 65.7 & 378 & 72.1 & 183 & 20.9 & 106.4 & 13.5 \\
\hline Big_Ridge_M4_12 & 376 & 920 & 717 & 1043 & 49 & 2.8 & 615 & 2160 & 320 & 1334 & 296 & 23.2 & 267 & 35.4 & 205 & 38.2 & 95.2 & 11.83 & 64.5 & 8.29 \\
\hline Big_Ridge_M4_13 & 220 & 936 & 593 & 1355 & 19.3 & 17.7 & 349 & 1287 & 189 & 852 & 243 & 15.66 & 253 & 41.1 & 267 & 51.8 & 131.4 & 15.5 & 82.4 & 10.67 \\
\hline Big_Ridge_M4_14 & 258 & 945 & 569 & 1370 & 17.8 & 2.05 & 360 & 1120 & 197 & 1010 & 301 & 18.3 & 303 & 43.4 & 261 & 47.5 & 117 & 14.3 & 71.9 & 9.1 \\
\hline Big_Ridge_M4_15 & 246 & 886 & 614 & 1270 & 15.2 & 2.84 & 394 & 1450 & 228 & 1089 & 298 & 21.7 & 309 & 43.2 & 244 & 43.7 & 107 & 12.5 & 64.4 & 7.99 \\
\hline Big_Ridge_M4_16 & 203 & 728 & 505 & 1616 & 22.4 & 2.54 & 493 & 1327 & 248 & 1385 & 400 & 25.6 & 413 & 59.7 & 339 & 61.5 & 157 & 17.5 & 87.3 & 11.35 \\
\hline Big_Ridge_M4_17 & 318 & 900 & 652 & 1250 & 24.9 & 1.61 & 401 & 1240 & 196 & 1000 & 280 & 20 & 273 & 39 & 217 & 39.2 & 97 & 11.5 & 57.5 & 7.94 \\
\hline Big_Ridge_M4_18 & 264 & 873 & 625 & 1530 & 40.3 & 6.1 & 523 & 1950 & 315 & 1380 & 381 & 25.2 & 406 & 58.5 & 310 & 58 & 140 & 17.1 & 86 & 10.9 \\
\hline Big_Ridge_M4_19 & 291 & 709 & 614 & 1340 & 45.9 & 1.92 & 608 & 1660 & 281 & 1399 & 345 & 25.1 & 345 & 47.1 & 257 & 47.4 & 121 & 13.9 & 70.1 & 9 \\
\hline Big_Ridge_M4_20 & 215 & 721 & 511 & 1670 & 25 & 3.81 & 529 & 1620 & 267 & 1360 & 382 & 26.4 & 384 & 56.3 & 349 & 61.1 & 148 & 18.1 & 90 & 12 \\
\hline Big_Ridge_M4_21 & 379 & 864 & 643 & 1560 & 19.7 & 3.24 & 591 & 2240 & 339 & 1520 & 373 & 24.3 & 353 & 52.6 & 307 & 58.5 & 145 & 16.9 & 85.9 & 11.2 \\
\hline Big_Ridge_M4_22 & 198 & 846 & 571 & 1042 & 12.3 & 2.21 & 399 & 1386 & 221 & 1010 & 259 & 19.4 & 257 & 35.8 & 200 & 36.2 & 90.5 & 10.29 & 53 & 6.74 \\
\hline Big_Ridge_M4_23 & 296 & 855 & 587 & 1224 & 12.19 & 2.44 & 477 & 1550 & 256 & 1225 & 316 & 22.6 & 306 & 42.7 & 242 & 44.5 & 106.3 & 12.35 & 64.3 & 8.05 \\
\hline Big_Ridge_M4_24 & 243 & 846 & 602 & 778 & 29.1 & 1.48 & 491 & 1560 & 231 & 1049 & 233 & 19.7 & 218 & 29.7 & 156 & 27.8 & 70.7 & 7.98 & 40.4 & 5.47 \\
\hline
\end{tabular}


Table A1. Cont.

\begin{tabular}{|c|c|c|c|c|c|c|c|c|c|c|c|c|c|c|c|c|c|c|c|c|}
\hline Sample Name & Mg & Mn & $\mathrm{Fe}$ & $\mathbf{Y}$ & Th & $\mathbf{U}$ & La & $\mathrm{Ce}$ & Pr & Nd & Sm & Eu & Gd & $\mathrm{Tb}$ & Dy & Ho & Er & $\mathrm{Tm}$ & $\mathrm{Yb}$ & Lu \\
\hline BR0417_D1_1 & 843 & 460.9 & 772 & 1180 & 19.47 & 6.53 & 1011 & 3165 & 420 & 1805 & 371.9 & 28.51 & 345.1 & 45.5 & 253.5 & 46.7 & 116.9 & 13.39 & 68.7 & 8.85 \\
\hline BR0417_D1_2 & 855 & 445.6 & 743 & 1030 & 17 & 3.52 & 866 & 2679 & 361 & 1549 & 322 & 25.76 & 298.9 & 39.1 & 219.6 & 40.4 & 101.5 & 11.47 & 59.3 & 7.58 \\
\hline BR0417_D1_3 & 801 & 442.3 & 772 & 764 & 9.13 & 2.03 & 672 & 2002 & 273.3 & 1185 & 247.4 & 19.98 & 225.6 & 29.48 & 165.1 & 30.2 & 75.5 & 8.54 & 43.9 & 5.62 \\
\hline BR0417_D1_5 & 707 & 503 & 825 & 781 & 15.5 & 3.99 & 1001 & 2900 & 358 & 1419 & 260 & 19.1 & 231 & 28.5 & 159 & 29.9 & 77.4 & 9.17 & 49 & 6.54 \\
\hline BR0417_D1_6 & 820 & 452.9 & 820 & 717 & 9.04 & 2.47 & 729 & 2147 & 284.3 & 1210 & 239.8 & 18.52 & 214.6 & 27.3 & 153.2 & 28.28 & 71.9 & 8.22 & 42.4 & 5.43 \\
\hline BR0417_D1_7 & 796 & 445 & 729 & 703 & 9.6 & 1.96 & 670 & 2010 & 263 & 1102 & 219 & 17.5 & 201 & 26.1 & 144.7 & 26.7 & 67.3 & 7.73 & 40.4 & 5.2 \\
\hline BR0417_D1_8 & 774 & 423.6 & 704 & 580 & 5.12 & 2.85 & 561 & 1629 & 218.5 & 923 & 186.6 & 14.84 & 171.3 & 21.82 & 122.4 & 22.4 & 55.7 & 6.24 & 31.9 & 4.121 \\
\hline BR0417_D1_10 & 818 & 454.5 & 751 & 1207 & 21.8 & 4.85 & 1022 & 3110 & 421 & 1810 & 379 & 28.9 & 345 & 45.5 & 256 & 46.9 & 118.3 & 13.49 & 69.2 & 8.88 \\
\hline BR0417_D1_11 & 893 & 464.6 & 719 & 526 & 5.16 & 1.35 & 607 & 1797 & 226.4 & 913 & 173.4 & 13.65 & 153.1 & 19.45 & 107 & 19.67 & 49.9 & 5.71 & 30.1 & 3.97 \\
\hline BR0417_D1_12 & 734 & 483.7 & 725 & 938 & 18.3 & 3.94 & 1183 & 3379 & 424 & 1681 & 304.8 & 23.01 & 269.9 & 33.9 & 189.7 & 35.2 & 91.5 & 11.01 & 59 & 7.86 \\
\hline BR0417_D1_13 & 750 & 438.2 & 801 & 528.8 & 3.88 & 1.084 & 555 & 1585 & 209.6 & 880 & 171.1 & 13.83 & 157.9 & 19.66 & 109.1 & 20.09 & 50.5 & 5.79 & 29.82 & 3.9 \\
\hline BR0417_D1_14 & 689 & 520 & 751 & 1039 & 31.6 & 6.06 & 1406 & 4130 & 502 & 1937 & 337 & 25.8 & 296 & 36.6 & 207.7 & 38.7 & 101.7 & 12.31 & 67.5 & 9.06 \\
\hline BR0417_D1_15 & 794 & 445.6 & 732 & 1064 & 14.9 & 3.22 & 940 & 2780 & 374 & 1639 & 336 & 26.3 & 309 & 39.5 & 223.5 & 40.7 & 102 & 11.83 & 60.4 & 7.79 \\
\hline BR0417_D1_16 & 684 & 455.8 & 703 & 827 & 16.1 & 4.05 & 924 & 2690 & 346 & 1404 & 266 & 20.3 & 239 & 29.7 & 167 & 31.1 & 79.8 & 9.44 & 50.1 & 6.58 \\
\hline BR0417_D1_17 & 802 & 441.2 & 727 & 1199 & 24.1 & 4.68 & 1084 & 3240 & 434 & 1851 & 379 & 29 & 344 & 44.5 & 251 & 45.8 & 115.4 & 13.37 & 70.2 & 9.01 \\
\hline BR0417_D2_1 & 949 & 465 & 1377 & 453 & 2.36 & 0.973 & 465 & 1494 & 184.1 & 750 & 146.2 & 12.35 & 126.4 & 16.19 & 90.9 & 16.94 & 42.4 & 4.82 & 25 & 3.28 \\
\hline BR0417_D2_3 & 934 & 503 & 916 & 733 & 7.04 & 2.14 & 686 & 2424 & 307 & 1184 & 243.4 & 19.65 & 219.1 & 27.43 & 153.8 & 28.62 & 71.1 & 7.96 & 41.7 & 5.37 \\
\hline BR0417_D2_4 & 999 & 496 & 944 & 588 & 5.09 & 7 & 540 & 1842 & 229.7 & 940 & 189.3 & 16.41 & 177.9 & 22.5 & 125.6 & 22.8 & 57.1 & 6.36 & 32.5 & 4.22 \\
\hline BR0417_D2_5 & 945 & 494 & 923 & 872 & 12.4 & 10.9 & 713 & 2440 & 305.2 & 1267 & 257.9 & 21.73 & 232.5 & 30.08 & 172.6 & 32.6 & 86.1 & 11.02 & 66 & 9.2 \\
\hline BR0417_D2_6 & 842 & 483 & 1001 & 672 & 5.62 & 1.81 & 623 & 2159 & 266.9 & 1082 & 212.7 & 17.25 & 197.4 & 24.83 & 138.2 & 25.21 & 62.9 & 7.07 & 36.3 & 4.67 \\
\hline BR0417_D2_7 & 924 & 455 & 870 & 707 & 5.81 & 1.659 & 607 & 2061 & 260.5 & 1092 & 224.8 & 18.63 & 203 & 26.47 & 147.9 & 26.96 & 67.4 & 7.6 & 38.8 & 5.03 \\
\hline BR0417_D2_8 & 914 & 472 & 865 & 1039 & 16.1 & 4.96 & 861 & 2930 & 365 & 1581 & 322 & 26.7 & 300 & 38.8 & 218 & 39.5 & 97.8 & 11.34 & 58.5 & 7.41 \\
\hline BR0417_D2_9 & 894 & 442 & 850 & 548 & 2.89 & 1.032 & 490 & 1604 & 204.8 & 851 & 176.4 & 14.91 & 162 & 20.47 & 114 & 20.61 & 51.4 & 5.77 & 29.15 & 3.8 \\
\hline BR0417_D2_10 & 870 & 434 & 827 & 958 & 13.49 & 5.17 & 805 & 2430 & 329.7 & 1428 & 297 & 24 & 275 & 35.5 & 198.5 & 36.7 & 91 & 10.57 & 54.4 & 6.94 \\
\hline BR0417_D2_11 & 951 & 480 & 906 & 739 & 6.86 & 2.9 & 650 & 2217 & 275.2 & 1155 & 229.8 & 19.2 & 212.6 & 27.3 & 152 & 28.07 & 69.1 & 8.02 & 41.2 & 5.31 \\
\hline BR0417_D2_12 & 870 & 435 & 840 & 478 & 1.937 & 0.667 & 445 & 1430 & 181.3 & 754 & 149.6 & 12.54 & 140.5 & 17.52 & 97.4 & 17.73 & 44.4 & 4.95 & 25.37 & 3.32 \\
\hline BR0417_D2_13 & 827 & 478 & 895 & 546 & 3.81 & 2.48 & 555 & 1789 & 222.4 & 909 & 174.4 & 14.23 & 159.2 & 20 & 112.4 & 20.51 & 50.6 & 5.77 & 29.7 & 3.83 \\
\hline BR0417_D2_14 & 911 & 477 & 1021 & 781 & 7 & 2.044 & 691 & 2349 & 293.8 & 1216 & 240.2 & 19.54 & 219.9 & 28.74 & 159.1 & 29.53 & 73.2 & 8.36 & 42.5 & 5.51 \\
\hline BR0417_D2_15 & 980 & 481 & 953 & 610 & 6.11 & 1.804 & 524 & 1827 & 229.1 & 925 & 192 & 17.98 & 176.3 & 22.61 & 125.3 & 22.76 & 58 & 6.56 & 34.5 & 4.42 \\
\hline BR0417_D2_16 & 771 & 533 & 877 & 690 & 10.09 & 2.51 & 838 & 2890 & 329 & 1239 & 229.1 & 18.82 & 205 & 25.32 & 139 & 25.7 & 65.8 & 7.64 & 41.3 & 5.47 \\
\hline BR0417_D2_17 & 1037 & 528 & 1055 & 1303 & 27.2 & 10.1 & 1220 & 4360 & 524 & 2120 & 423 & 33.5 & 386 & 48.7 & 272 & 49.8 & 124.5 & 14.29 & 75.1 & 9.55 \\
\hline BR0417_D2_18 & 912 & 489 & 912 & 566 & 4.2 & 1.259 & 527 & 1851 & 216.6 & 910 & 183.4 & 15.27 & 164.1 & 20.73 & 117.8 & 21.74 & 53.1 & 6.01 & 30.5 & 3.99 \\
\hline BR0417_D2_19 & 1025 & 510 & 999 & 638 & 6.11 & 1.737 & 581 & 2126 & 251.4 & 1037 & 203.6 & 17.72 & 186.5 & 23.83 & 132.1 & 24.19 & 61.1 & 6.97 & 36.1 & 4.65 \\
\hline BR0417_D2_20 & 970 & 483 & 967 & 796 & 7.57 & 2.21 & 700 & 2434 & 299 & 1248 & 253.5 & 21.58 & 234.5 & 30.01 & 169.2 & 31.05 & 77.6 & 8.74 & 44.3 & 5.77 \\
\hline
\end{tabular}


Table A1. Cont.

\begin{tabular}{|c|c|c|c|c|c|c|c|c|c|c|c|c|c|c|c|c|c|c|c|c|}
\hline Sample Name & Mg & Mn & $\mathrm{Fe}$ & $\mathbf{Y}$ & Th & $\mathbf{U}$ & La & $\mathrm{Ce}$ & Pr & Nd & Sm & Eu & Gd & $\mathrm{Tb}$ & Dy & Ho & Er & $\mathrm{Tm}$ & $\mathrm{Yb}$ & $\mathbf{L u}$ \\
\hline BR0417_D3_1 & 811 & 474.5 & 925 & 934 & 18.7 & 4.41 & 989 & 3090 & 386 & 1558 & 295 & 23.8 & 260 & 33.3 & 187 & 34.4 & 87.8 & 10.32 & 54.6 & 7.19 \\
\hline BR0417_D3_2 & 795 & 461 & 780 & 816 & 11.48 & 2.43 & 761 & 2420 & 310 & 1292 & 260 & 20.43 & 237 & 30.7 & 170.1 & 31.5 & 79.8 & 9.14 & 47.3 & 6.11 \\
\hline BR0417_D3_3 & 1350 & 445.4 & 939 & 830 & 11.25 & 2.95 & 699 & 2261 & 288.8 & 1238 & 254.3 & 23.95 & 232.9 & 30.37 & 170 & 30.9 & 77.4 & 8.75 & 45.6 & 5.91 \\
\hline BR0417_D3_5 & 946 & 413.1 & 1003 & 598 & 7.74 & 2.197 & 456 & 1442 & 194.2 & 850 & 182.2 & 24.4 & 165.6 & 21.61 & 121.1 & 21.93 & 54.5 & 6.26 & 32.7 & 4.31 \\
\hline BR0417_D3_6 & 865 & 467.5 & 826 & 999 & 13.8 & 3.3 & 856 & 2770 & 359 & 1513 & 311 & 24.4 & 286 & 36.7 & 207.7 & 37.7 & 94.2 & 10.74 & 55.7 & 7.27 \\
\hline BR0417_D3_7 & 838 & 465.4 & 824 & 945 & 16.7 & 5.17 & 965 & 3050 & 378 & 1538 & 302 & 22.9 & 267 & 33.8 & 186.5 & 34.3 & 87.2 & 10.11 & 53.7 & 7.09 \\
\hline BR0417_D3_8 & 1305 & 562 & 1100 & 681 & 11.93 & 2.82 & 551 & 1685 & 228.8 & 992 & 211.8 & 25.04 & 188.5 & 24.21 & 134.3 & 24.57 & 60.4 & 7 & 37.4 & 4.91 \\
\hline BR0417_D3_10 & 1172 & 415 & 1011 & 636 & 8.39 & 2.16 & 532 & 1717 & 222.9 & 978 & 206.3 & 23.4 & 189 & 24.2 & 135.6 & 24.9 & 62 & 6.93 & 35.3 & 4.6 \\
\hline BR0417_D3_11 & 760 & 485 & 834 & 954 & 14.74 & 3.63 & 995 & 3140 & 397 & 1573 & 298 & 23.3 & 269.1 & 33.7 & 189.2 & 35.2 & 90.2 & 10.54 & 55.9 & 7.3 \\
\hline BR0417_D3_12 & 799 & 436.2 & 741 & 678 & 12.9 & 2.01 & 676 & 2048 & 267 & 1103 & 223.1 & 18.16 & 197.4 & 24.9 & 138.3 & 25.3 & 63.7 & 7.3 & 38.2 & 4.94 \\
\hline BR0417_D3_13 & 896 & 458.8 & 904 & 969 & 16.6 & 3.45 & 828 & 2700 & 347 & 1474 & 301 & 24.4 & 277 & 35.5 & 198 & 36.5 & 90.9 & 10.33 & 53.6 & 6.89 \\
\hline BR0417_D4_1 & 892 & 489 & 876 & 827 & 8.12 & 2.24 & 729 & 2470 & 308.2 & 1291 & 264.7 & 21.01 & 242 & 31.1 & 174.5 & 32 & 79 & 8.99 & 46.4 & 5.96 \\
\hline BR0417_D4_2 & 906 & 533 & 1290 & 653 & 5.32 & 1.801 & 635 & 2092 & 266 & 1062 & 217.6 & 18.54 & 195.7 & 24.24 & 135 & 24.91 & 62.4 & 7.06 & 36.1 & 4.75 \\
\hline BR0417_D4_3 & 662 & 592 & 891 & 676 & 11.36 & 3.95 & 907 & 2780 & 328.5 & 1269 & 224.1 & 14.61 & 195.6 & 24.16 & 133.6 & 25.04 & 65.4 & 7.91 & 42.4 & 5.71 \\
\hline BR0417_D4_4 & 809 & 483.2 & 856 & 808 & 10.48 & 2.52 & 718 & 2109 & 281.9 & 1232 & 246.6 & 20.68 & 228.6 & 29.39 & 163.7 & 30.16 & 76.1 & 8.77 & 45.9 & 6.01 \\
\hline BR0417_D4_5 & 779 & 418.2 & 770 & 1139 & 18.34 & 6.8 & 971 & 2772 & 385.8 & 1695 & 348.9 & 26.09 & 317.8 & 41.57 & 232.8 & 42.77 & 107.4 & 12.33 & 64 & 8.28 \\
\hline BR0417_D4_7 & 668 & 482 & 776 & 749 & 6.97 & 1.79 & 685 & 2050 & 274.7 & 1166 & 238 & 18.58 & 220.1 & 27.9 & 154.9 & 28.8 & 71.2 & 8.04 & 40.9 & 5.33 \\
\hline BR0417_D4_8 & 788 & 471 & 951 & 1085 & 22.2 & 4.68 & 1136 & 3490 & 441 & 1770 & 338 & 26.03 & 301.6 & 38.3 & 216.9 & 40.3 & 102.9 & 12.15 & 64.5 & 8.61 \\
\hline BR0417_D4_9 & 957 & 502 & 1131 & 1025 & 11.05 & 8.96 & 702 & 2360 & 295 & 1272 & 275.2 & 20.1 & 285.3 & 40.2 & 236 & 45 & 109.4 & 11.66 & 56.8 & 7.27 \\
\hline BR0417_D4_10 & 712 & 608 & 1183 & 557 & 6.31 & 1.712 & 698 & 2137 & 256.8 & 1003 & 181.9 & 14.7 & 164 & 19.73 & 109.5 & 20.38 & 52.6 & 6.26 & 33.8 & 4.55 \\
\hline BR0417_D4_11 & 779 & 437.9 & 779 & 625 & 4.12 & 1.118 & 581 & 1706 & 228 & 968 & 195.1 & 15.45 & 177.4 & 22.81 & 127.1 & 23.34 & 58.2 & 6.61 & 34.23 & 4.48 \\
\hline BR0417_D4_12 & 765 & 545 & 955 & 958 & 24.18 & 6.37 & 1268 & 3820 & 451 & 1775 & 310.2 & 23.25 & 269.4 & 33.69 & 187.6 & 35.05 & 91.7 & 11 & 61 & 8.16 \\
\hline BR0417_D4_13 & 813 & 463.4 & 856 & 626 & 5.3 & 1.37 & 585 & 1732 & 227.7 & 985 & 199.5 & 16.16 & 181.4 & 23.1 & 127.8 & 23.63 & 59.2 & 6.67 & 34.4 & 4.47 \\
\hline BR0417_D4_14 & 1020 & 385.5 & 989 & 739 & 9.44 & 2.582 & 561 & 1715 & 238.1 & 1075 & 232.2 & 23.22 & 215.9 & 28.14 & 155.9 & 28.41 & 70 & 7.85 & 39.7 & 5.13 \\
\hline BR0417_D4_15 & 891 & 419.3 & 836 & 710 & 9.05 & 2.037 & 767 & 2144 & 279.4 & 1176 & 224.5 & 17.88 & 207.7 & 25.76 & 144.3 & 26.75 & 67.9 & 7.94 & 41.5 & 5.5 \\
\hline BR0417_D4_16 & 716 & 448 & 760 & 493 & 2.04 & 13.41 & 494 & 1382 & 184.8 & 790 & 155.4 & 12.59 & 144.5 & 18.57 & 102.3 & 18.57 & 45.9 & 5.15 & 26.58 & 3.56 \\
\hline BR0417_D4_17 & 631 & 556 & 839 & 603 & 6.99 & 2.22 & 784 & 2174 & 274.7 & 1116 & 196.2 & 13.64 & 175 & 22.19 & 121.4 & 22.98 & 60.1 & 6.94 & 36.7 & 4.9 \\
\hline BR0417_D5_1 & 1022 & 436.3 & 844 & 788 & 14.43 & 2.9 & 668.2 & 2047 & 275.3 & 1189 & 247.8 & 21.14 & 226.1 & 29.13 & 164.4 & 30.17 & 75.7 & 8.64 & 44.9 & 5.69 \\
\hline BR0417_D5_2 & 771 & 442 & 690 & 542.2 & 3.18 & 1.028 & 543.7 & 1637 & 215.1 & 890 & 177.1 & 14.11 & 160.1 & 20.24 & 113.2 & 20.79 & 51.9 & 5.88 & 30.05 & 3.9 \\
\hline BR0417_D5_3 & 822 & 429.6 & 727 & 730 & 6.67 & 1.706 & 639 & 1937 & 257 & 1107 & 227.1 & 18.65 & 208 & 26.95 & 151.8 & 27.76 & 70.1 & 7.85 & 40.7 & 5.23 \\
\hline BR0417_D5_4 & 837 & 459.9 & 785 & 953 & 15.3 & 2.95 & 812 & 2545 & 338.1 & 1448 & 299.5 & 22.76 & 278.4 & 36 & 202.5 & 36.7 & 91.3 & 10.39 & 53.3 & 6.72 \\
\hline BR0417_D5_5 & 906 & 466.1 & 790 & 681 & 9.28 & 2.312 & 597.1 & 1879 & 246 & 1026 & 215.8 & 18.9 & 193.7 & 25.1 & 142 & 26.01 & 64.8 & 7.51 & 38.9 & 4.96 \\
\hline BR0417_D5_6 & 839 & 449 & 720 & 1194 & 21.5 & 3.73 & 966 & 2920 & 394 & 1750 & 371 & 29.6 & 347 & 45.1 & 253 & 46.1 & 116.6 & 13.3 & 69.2 & 8.84 \\
\hline
\end{tabular}


Table A1. Cont.

\begin{tabular}{|c|c|c|c|c|c|c|c|c|c|c|c|c|c|c|c|c|c|c|c|c|}
\hline Sample Name & $\mathrm{Mg}$ & Mn & $\mathrm{Fe}$ & $\mathbf{Y}$ & Th & $\mathbf{U}$ & La & $\mathrm{Ce}$ & Pr & Nd & Sm & Eu & Gd & $\mathrm{Tb}$ & Dy & Ho & Er & $\operatorname{Tm}$ & $\mathbf{Y b}$ & Lu \\
\hline BR0417_D5_7 & 959 & 501.2 & 793 & 488 & 10.85 & 2.73 & 693 & 2063 & 249.8 & 983 & 177.7 & 23.09 & 152.5 & 18.51 & 101 & 18.48 & 48.1 & 5.65 & 31.2 & 4.27 \\
\hline BR0417_D5_8 & 716 & 376.6 & 658 & 1435 & 28.1 & 4.98 & 1109 & 2460 & 391.1 & 1955 & 422.6 & 31.96 & 397.3 & 52.3 & 298.1 & 54.4 & 136.2 & 15.61 & 79.8 & 10.26 \\
\hline BR0417_D5_9 & 879 & 470.9 & 781 & 1674 & 43.3 & 8.79 & 1317 & 4230 & 572 & 2450 & 528 & 41.1 & 484 & 64.7 & 360 & 66.3 & 165.2 & 18.9 & 97.2 & 12.37 \\
\hline BR0417_D5_11 & 802 & 544 & 796 & 1205 & 23.5 & 5.32 & 1171 & 3690 & 466 & 1935 & 377 & 29 & 339 & 44 & 249.8 & 46 & 119 & 13.91 & 73.6 & 9.52 \\
\hline BR0417_D5_12 & 859 & 455.6 & 787 & 981 & 24.4 & 4.92 & 904 & 2770 & 363 & 1531 & 311 & 25.1 & 285 & 36.5 & 206 & 37.8 & 95.3 & 11.04 & 58 & 7.46 \\
\hline BR0417_D5_13 & 820 & 436.5 & 710 & 954 & 12.45 & 3.04 & 795 & 2477 & 331 & 1404 & 294.1 & 23.52 & 271.2 & 35.4 & 198.2 & 36.3 & 91 & 10.4 & 53 & 6.76 \\
\hline BR0417_D5_14 & 826 & 455 & 741 & 845 & 24.1 & 2.76 & 766 & 2320 & 310 & 1321 & 273 & 23.6 & 251 & 32.6 & 181 & 32.8 & 82 & 9.43 & 48.9 & 6.28 \\
\hline BR0417_D5_16 & 819 & 450.7 & 777 & 875 & 27.1 & 24.9 & 718 & 2159 & 283.4 & 1206 & 248.3 & 19.97 & 224.8 & 29.41 & 173.8 & 33.5 & 93.2 & 13.11 & 85.9 & 12.37 \\
\hline BR0417_D5_17 & 882 & 452.6 & 745 & 897 & 16 & 7.52 & 761 & 2375 & 314.5 & 1338 & 278.3 & 23.84 & 255.8 & 33.44 & 188.4 & 34.36 & 85.3 & 9.72 & 49.8 & 6.39 \\
\hline BR0417_D6_1 & 884 & 422.3 & 819 & 938 & 53.9 & 2.979 & 905 & 2051 & 299.8 & 1368 & 273.1 & 28 & 240.2 & 31.07 & 178.5 & 33.8 & 88 & 10.71 & 57.4 & 7.61 \\
\hline BR0417_D6_2 & 778 & 398.9 & 732 & 958 & 20.6 & 2.92 & 834 & 2152 & 305 & 1410 & 290.9 & 23.76 & 262.7 & 33.9 & 191.8 & 35.4 & 89 & 10.29 & 53.9 & 7.04 \\
\hline BR0417_D6_3 & 825 & 430 & 849 & 775 & 13.19 & 1.763 & 730 & 2000 & 271.3 & 1189 & 242.2 & 20.19 & 216.8 & 28.08 & 157.1 & 29.05 & 73.6 & 8.48 & 44.6 & 5.78 \\
\hline BR0417_D6_4 & 884 & 438 & 829 & 1226 & 17.77 & 5.3 & 966 & 3034 & 409 & 1763 & 358 & 29.2 & 342 & 44.1 & 253.1 & 46.2 & 116.2 & 13.47 & 69.3 & 8.86 \\
\hline BR0417_D6_5 & 811 & 463 & 807 & 750 & 8.81 & 2.21 & 727 & 2193 & 285.7 & 1211 & 236.4 & 19.09 & 217.9 & 27.3 & 154.2 & 27.91 & 69.7 & 8 & 41.9 & 5.47 \\
\hline BR0417_D6_6 & 1302 & 541 & 1893 & 635 & 9.53 & 3.32 & 505 & 1480 & 206.4 & 913 & 187.5 & 18.98 & 178 & 22.88 & 130.2 & 24 & 61.2 & 7 & 36.1 & 4.84 \\
\hline BR0417_D6_7 & 1143 & 431 & 1039 & 694 & 9 & 2.289 & 550 & 1716 & 229 & 996 & 217.4 & 23.77 & 199 & 25.98 & 143.9 & 26.19 & 64.9 & 7.42 & 38.1 & 4.95 \\
\hline BR0417_D7_2 & 947 & 421.5 & 763 & 1041 & 25.2 & 2.414 & 829 & 2361 & 327.6 & 1482 & 323.7 & 27.72 & 300.6 & 39.16 & 217.2 & 39.87 & 99.3 & 11.38 & 58.9 & 7.46 \\
\hline BR0417_D7_3 & 822 & 424.5 & 776 & 1012 & 24.83 & 3.39 & 803 & 2364 & 322.2 & 1432 & 301.8 & 24.68 & 283.8 & 37.12 & 208.1 & 38.17 & 95.3 & 10.9 & 56.6 & 7.24 \\
\hline BR0417_D7_4 & 815 & 453.5 & 845 & 635 & 7.55 & 2.308 & 674 & 2058 & 261.4 & 1072 & 206.8 & 16.74 & 180.3 & 22.95 & 127.7 & 23.29 & 59.3 & 6.83 & 36.03 & 4.71 \\
\hline BR0417_D7_5 & 831 & 415.6 & 780 & 1068 & 21.5 & 2.52 & 827 & 2267 & 322.7 & 1470 & 317.6 & 26.65 & 298.1 & 39.1 & 221.6 & 40.4 & 100.8 & 11.71 & 60.5 & 7.83 \\
\hline BR0417_D7_6 & 907 & 471.8 & 837 & 1214 & 29.7 & 3.31 & 985 & 2682 & 368.3 & 1709 & 364.3 & 25.18 & 346 & 44.82 & 251.3 & 45.85 & 114.8 & 13.18 & 68.9 & 8.9 \\
\hline BR0417_D7_7 & 967 & 427.3 & 786 & 710 & 5.95 & 1.433 & 600.2 & 1813 & 240.9 & 1066 & 220.7 & 17.97 & 206.6 & 25.87 & 146 & 26.65 & 66.1 & 7.43 & 38.36 & 4.97 \\
\hline BR0417_D7_8 & 811 & 422.4 & 740 & 804 & 9.85 & 1.965 & 710 & 2060 & 279.3 & 1226 & 249.8 & 20.5 & 232.1 & 29.95 & 168.3 & 31 & 77.8 & 8.81 & 45.2 & 5.88 \\
\hline BR0417_D7_9 & 855 & 441 & 798 & 1301 & 34.1 & 4.91 & 1085 & 3330 & 441 & 1899 & 397 & 32.5 & 357 & 47 & 266 & 48.8 & 123.1 & 14.46 & 75.3 & 9.62 \\
\hline BR0417_D7_10 & 794 & 466.8 & 802 & 1240 & 31.5 & 4.34 & 1130 & 3100 & 425 & 1883 & 379 & 31.4 & 346 & 44.7 & 251 & 46.5 & 119.1 & 14.02 & 74.4 & 9.8 \\
\hline BR0417_B1_1 & 2046 & 637 & 1083 & 566 & 9.2 & 1.92 & 421 & 1026 & 151.8 & 713 & 156.4 & 26.6 & 147.7 & 20.6 & 119.1 & 21.9 & 56.7 & 6.51 & 34.1 & 4.67 \\
\hline BR0417_B1_2 & 1941 & 616 & 1126 & 737 & 17.2 & 2.97 & 576 & 1363 & 199.1 & 953 & 210 & 26.7 & 192 & 25.9 & 146.9 & 26.9 & 68.4 & 7.99 & 41.8 & 5.69 \\
\hline BR0417_B1_3 & 1860 & 652 & 1052 & 558 & 37.4 & 2.17 & 438 & 1097 & 162 & 771 & 163 & 28.3 & 149 & 20.7 & 116 & 21.4 & 53.5 & 6.27 & 33.3 & 4.73 \\
\hline BR0417_B1_4 & 1588 & 719 & 1067 & 843 & 14.9 & 3.42 & 670 & 1641 & 235 & 1097 & 248 & 34.1 & 232 & 31.9 & 187 & 34.1 & 85.4 & 9.9 & 52.1 & 7.12 \\
\hline BR0417_B1_5 & 2092 & 544 & 1038 & 703 & 13.66 & 2.54 & 488 & 1002 & 159.3 & 858 & 199.9 & 31.9 & 190 & 26.2 & 152.6 & 28.1 & 70.7 & 8.12 & 41.8 & 5.63 \\
\hline BR0417_B1_6 & 1226 & 739 & 1006 & 1063 & 19 & 4.08 & 738 & 1760 & 261 & 1336 & 298 & 45.8 & 276 & 39.6 & 228 & 42.9 & 108 & 12.6 & 65.2 & 8.88 \\
\hline BR0417_B1_7 & 994 & 725 & 806 & 1389 & 61.2 & 4.98 & 1052 & 2610 & 371 & 1850 & 415 & 47.3 & 376 & 52.3 & 299 & 55.8 & 139 & 16.2 & 84.3 & 11.6 \\
\hline BR0417_B1_8 & 2357 & 592 & 1177 & 545 & 13.9 & 3.44 & 435 & 1092 & 161.7 & 794 & 175 & 28.1 & 169 & 23.2 & 134 & 24.1 & 60.2 & 6.98 & 35.9 & 4.94 \\
\hline
\end{tabular}


Table A1. Cont.

\begin{tabular}{|c|c|c|c|c|c|c|c|c|c|c|c|c|c|c|c|c|c|c|c|c|}
\hline Sample Name & $\mathrm{Mg}$ & Mn & $\mathrm{Fe}$ & $\mathbf{Y}$ & Th & $\mathbf{U}$ & La & $\mathrm{Ce}$ & Pr & Nd & Sm & Eu & Gd & $\mathrm{Tb}$ & Dy & Ho & Er & $\operatorname{Tm}$ & $\mathbf{Y b}$ & Lu \\
\hline BR0417_B1_9 & 1927 & 666 & 1110 & 638 & 11.3 & 2.51 & 489 & 1243 & 179.2 & 859 & 194 & 30.5 & 177 & 25 & 142 & 26.2 & 65.7 & 7.55 & 39.8 & 5.41 \\
\hline BR0417_B1_10 & 1674 & 669 & 1066 & 793 & 14 & 3.1 & 607 & 1490 & 216 & 1027 & 239 & 32.6 & 214 & 30.2 & 174 & 32.5 & 82 & 9.46 & 49.9 & 6.72 \\
\hline BR0417_B1_11 & 2260 & 585 & 1073 & 569 & 16 & 2.83 & 398 & 984 & 149.1 & 735 & 165.2 & 30.5 & 156 & 21.7 & 122.6 & 22.9 & 59 & 7.12 & 37 & 4.98 \\
\hline BR0417_B1_13 & 2329 & 601 & 1150 & 484 & 12.7 & 2.49 & 372 & 935 & 137 & 691 & 151 & 27.3 & 145 & 19.2 & 112.7 & 20.6 & 50.4 & 5.7 & 29.7 & 4.06 \\
\hline BR0417_B1_14 & 1959 & 639 & 1095 & 709 & 24.1 & 2.98 & 546 & 1328 & 194 & 944 & 209 & 33.2 & 194 & 27.1 & 155 & 29.2 & 74.3 & 8.6 & 44.5 & 6.08 \\
\hline BR0417_B1_15 & 1448 & 666 & 999 & 1125 & 58.5 & 4.26 & 859 & 2017 & 303 & 1512 & 354 & 45.2 & 326 & 44.1 & 249 & 46.5 & 119.3 & 14 & 72.4 & 9.81 \\
\hline BR0417_B1_16 & 1317 & 753 & 1067 & 958 & 18.6 & 2.84 & 765 & 1904 & 273 & 1313 & 285 & 33.9 & 270 & 36.7 & 208 & 38.3 & 96.7 & 11 & 57.2 & 7.8 \\
\hline BR0417_B1_18 & 2240 & 562 & 1074 & 634 & 24.4 & 3.1 & 436 & 1030 & 164 & 803 & 192 & 32.1 & 171 & 24.6 & 133 & 25.1 & 65 & 7.8 & 40.6 & 5.7 \\
\hline BR0417_B1_19 & 1745 & 667 & 1052 & 782 & 13.2 & 3.29 & 609 & 1560 & 227 & 1036 & 237 & 35.1 & 217 & 30.4 & 170 & 32.4 & 80.5 & 9.4 & 48.2 & 6.53 \\
\hline BR0417_B1_20 & 1801 & 750 & 1035 & 703 & 14.7 & 3.28 & 511 & 1330 & 195 & 926 & 212 & 35.1 & 200 & 27.3 & 158 & 30.2 & 79 & 9.5 & 49.5 & 6.6 \\
\hline BR0417_B2_1 & 1871 & 658 & 1095 & 811 & 18.4 & 4.24 & 628 & 1572 & 225.6 & 1088 & 241.4 & 33 & 223 & 30.7 & 180.3 & 32.7 & 82.9 & 9.76 & 51.9 & 7.06 \\
\hline BR0417_B2_2 & 812 & 441 & 802 & 1204 & 20 & 4.23 & 989 & 2570 & 372 & 1762 & 381 & 27.7 & 340 & 47.2 & 270 & 49.3 & 126.8 & 14.4 & 73.9 & 9.65 \\
\hline BR0417_B2_3 & 777 & 447 & 707 & 1009 & 8.5 & 2.27 & 837 & 2200 & 320 & 1485 & 309 & 22.1 & 273 & 37.6 & 212 & 39.6 & 99.1 & 11.5 & 59 & 7.93 \\
\hline BR0417_B2_4 & 837 & 447 & 717 & 1047 & 11.9 & 3 & 783 & 2180 & 322 & 1443 & 314 & 24.3 & 289 & 39.2 & 224 & 40.1 & 102.1 & 12 & 58.6 & 7.75 \\
\hline BR0417_B2_5 & 1342 & 690 & 1028 & 1101 & 16.5 & 2.99 & 831 & 1709 & 270 & 1397 & 328 & 35.1 & 300 & 41.8 & 236 & 43.4 & 111.3 & 12.9 & 66.7 & 8.69 \\
\hline BR0417_B2_6 & 1714 & 588 & 1028 & 1079 & 37.3 & 3.62 & 742 & 1529 & 248 & 1345 & 325 & 42.8 & 315 & 41.8 & 235 & 42.8 & 107.9 & 13.1 & 66.9 & 9.1 \\
\hline BR0417_B2_8 & 2129 & 643 & 1145 & 470 & 8.22 & 2.09 & 316 & 800 & 117.2 & 573 & 128.6 & 24.4 & 125.5 & 17.1 & 98.9 & 17.8 & 45.7 & 5.4 & 28.8 & 4.17 \\
\hline BR0417_B2_9 & 2151 & 653 & 1206 & 794 & 20.4 & 4.35 & 568 & 1448 & 209.5 & 1023 & 222 & 34.4 & 216 & 29.4 & 170 & 31.6 & 81.8 & 9.41 & 50.4 & 7.23 \\
\hline BR0417_B2_10 & 797 & 849 & 1018 & 1990 & 31.7 & 6.12 & 1397 & 3230 & 500 & 2590 & 607 & 60.5 & 560 & 78.8 & 446 & 81.3 & 198 & 22.6 & 118 & 15.7 \\
\hline BR0417_B2_11 & 1801 & 604 & 1116 & 939 & 20.6 & 3.67 & 651 & 1411 & 227 & 1193 & 274 & 39.8 & 257 & 36.7 & 210 & 39 & 99 & 11.5 & 59.5 & 8.11 \\
\hline BR0417_B2_12 & 1824 & 655 & 1156 & 901 & 19.5 & 4.18 & 660 & 1547 & 236 & 1123 & 253 & 38.1 & 248 & 34.9 & 198 & 37.4 & 95.7 & 11.4 & 59.8 & 8.22 \\
\hline BR0417_B2_13 & 1985 & 669 & 1225 & 736 & 17.9 & 4.21 & 548 & 1383 & 208 & 959 & 220 & 33.8 & 209 & 29.6 & 171 & 33.2 & 86 & 10.1 & 54.8 & 7.4 \\
\hline BR0417_B2_14 & 896 & 502 & 915 & 1537 & 42.1 & 5.94 & 883 & 2390 & 355 & 1870 & 448 & 43.3 & 440 & 62 & 358 & 66 & 167 & 19.2 & 100 & 13.4 \\
\hline BR0417_B2_15 & 1288 & 768 & 1111 & 817 & 12.6 & 3.01 & 604 & 1488 & 218 & 987 & 220 & 34 & 217 & 29.2 & 165 & 30.8 & 80.8 & 9.63 & 52.2 & 7.25 \\
\hline BR0417_B2_16 & 1420 & 677 & 1084 & 949 & 15.5 & 2.89 & 645 & 1368 & 222 & 1188 & 281 & 41.4 & 262 & 38 & 217 & 40.9 & 104 & 12 & 61.8 & 8.4 \\
\hline BR0417_B2_17 & 1931 & 633 & 1174 & 908 & 26.9 & 3.89 & 652 & 1530 & 226 & 1161 & 270 & 40.3 & 249 & 35.6 & 199 & 37.1 & 95 & 11 & 58 & 8.1 \\
\hline BR0417_B2_18 & 1820 & 581 & 1107 & 688 & 13.6 & 2.6 & 518 & 1277 & 189 & 902 & 203 & 28.1 & 189 & 26.2 & 151 & 27.5 & 71.6 & 8.2 & 42.6 & 5.92 \\
\hline BR0417_B2_19 & 1941 & 771 & 1221 & 672 & 13.4 & 2.81 & 463 & 1151 & 174 & 836 & 199 & 36.7 & 199 & 26.4 & 149 & 28 & 71.7 & 8.32 & 44.3 & 6 \\
\hline BR0417B3_1 & 1027 & 764 & 813 & 1229 & 19.2 & 3.92 & 827 & 2098 & 301.6 & 1528 & 343 & 39.2 & 326 & 44.5 & 262 & 48.5 & 123.3 & 14.27 & 75.3 & 10.19 \\
\hline BR0417B3_2 & 1549 & 690 & 1126 & 1202 & 55.3 & 5.2 & 860 & 2039 & 297.7 & 1530 & 346 & 44.5 & 340 & 44.1 & 250 & 46 & 117.6 & 13.74 & 73 & 9.93 \\
\hline BR0417B3_3 & 723 & 1056 & 867 & 1495 & 39.7 & 7.75 & 1350 & 3540 & 481 & 2180 & 448 & 44.9 & 425 & 56.9 & 327 & 60.4 & 162 & 19.6 & 103.9 & 13.8 \\
\hline BR0417B3_4 & 1254 & 783 & 1017 & 994 & 24.2 & 3.5 & 743 & 1893 & 279 & 1353 & 293 & 37 & 287 & 39.1 & 226 & 42.4 & 108.2 & 12.6 & 66.1 & 8.69 \\
\hline BR0417B3_5 & 1969 & 633 & 1137 & 748 & 16.7 & 3.75 & 535 & 1397 & 195.7 & 946 & 208 & 31.9 & 205 & 26.8 & 153.1 & 28.8 & 74.8 & 8.77 & 45.5 & 6.41 \\
\hline BR0417B3_6 & 2240 & 663 & 1096 & 915 & 24.4 & 4.61 & 659 & 1680 & 238.8 & 1167 & 267 & 40.2 & 250 & 33 & 193.3 & 35.5 & 88.7 & 10.37 & 56.8 & 7.82 \\
\hline
\end{tabular}


Table A1. Cont.

\begin{tabular}{|c|c|c|c|c|c|c|c|c|c|c|c|c|c|c|c|c|c|c|c|c|}
\hline Sample Name & $\mathrm{Mg}$ & Mn & $\mathrm{Fe}$ & $\mathbf{Y}$ & Th & $\mathbf{U}$ & La & $\mathrm{Ce}$ & $\operatorname{Pr}$ & $\mathrm{Nd}$ & Sm & Eu & Gd & $\mathbf{T b}$ & Dy & Ho & Er & $\mathrm{Tm}$ & $\mathrm{Yb}$ & Lu \\
\hline BR0417B3_7 & 675 & 982 & 821 & 1084 & 42.5 & 3.97 & 1022 & 2590 & 357 & 1637 & 336 & 32.5 & 313 & 41 & 234 & 43.9 & 116.7 & 14.1 & 73.1 & 10 \\
\hline BR0417B3_8 & 1432 & 761 & 1097 & 885 & 29.3 & 2.52 & 671 & 1710 & 249 & 1200 & 263 & 32.6 & 257 & 34.3 & 195 & 36.1 & 94 & 11.2 & 60.3 & 8.02 \\
\hline BR0417B3_9 & 1363 & 660 & 941 & 945 & 25.3 & 2.88 & 648 & 1549 & 231.6 & 1203 & 275 & 34.1 & 265 & 35.6 & 200.8 & 36.6 & 93.1 & 10.66 & 56.5 & 7.39 \\
\hline BR0417B3_11 & 1723 & 699 & 1095 & 680 & 19.7 & 2.64 & 478 & 1262 & 180.6 & 867 & 192 & 31.7 & 190 & 24.8 & 139.2 & 26.3 & 66.9 & 7.81 & 43.5 & 5.87 \\
\hline BR0417B3_12 & 1738 & 767 & 1174 & 885 & 19.2 & 4.28 & 605 & 1559 & 230 & 1045 & 246 & 38.8 & 241 & 31.8 & 184 & 34.6 & 88 & 10.44 & 57.7 & 7.9 \\
\hline BR0417B3_13 & 1349 & 750 & 1022 & 993 & 19.9 & 4.37 & 766 & 1994 & 274 & 1308 & 275 & 32.8 & 275 & 36.4 & 208 & 39.2 & 101.6 & 11.87 & 63.4 & 8.31 \\
\hline BR0417B3_14 & 1085 & 791 & 1041 & 968 & 10.6 & 2.98 & 747 & 1950 & 262 & 1236 & 276 & 30.9 & 264 & 36.3 & 203 & 38.1 & 99.2 & 11.5 & 58.9 & 7.45 \\
\hline BR0417_A1_1 & 1186 & 630 & 840 & 1324 & 35.7 & 3.48 & 926 & 1843 & 299 & 1631 & 378 & 42.9 & 359 & 48.9 & 280 & 51.5 & 131 & 15.1 & 78.9 & 10.58 \\
\hline BR0417_A1_2 & 1479 & 598 & 768 & 911 & 33.8 & 3.28 & 639 & 1249 & 206.8 & 1109 & 256 & 36.4 & 243 & 33.8 & 193 & 36 & 92.5 & 10.97 & 58.3 & 8.07 \\
\hline BR0417_A1_3 & 1575 & 590 & 1034 & 1086 & 33.5 & 2.25 & 728 & 1295 & 225.2 & 1279 & 301 & 32.9 & 292 & 39 & 219 & 40.4 & 101 & 11.83 & 60 & 8.12 \\
\hline BR0417_A1_4 & 1207 & 649 & 908 & 1441 & 31.3 & 3.68 & 1049 & 2015 & 333 & 1777 & 405 & 40.3 & 394 & 53.9 & 300 & 54.6 & 139 & 16.1 & 85 & 11.5 \\
\hline BR0417_A1_5 & 1332 & 663 & 965 & 1001 & 24.2 & 2.4 & 729 & 1584 & 249.7 & 1274 & 293 & 34.6 & 275 & 38 & 212 & 38.4 & 98.7 & 11.45 & 59.2 & 8.06 \\
\hline BR0417_A1_6 & 753 & 458 & 743 & 1173 & 19.6 & 3.58 & 1055 & 2430 & 357 & 1676 & 337 & 25.4 & 311 & 42.2 & 239 & 43.4 & 115.1 & 13.7 & 71.7 & 9.6 \\
\hline BR0417_A1_7 & 1325 & 746 & 983 & 1030 & 18.1 & 2.84 & 803 & 1940 & 289 & 1398 & 295 & 32.7 & 281 & 38.5 & 217 & 39.8 & 103.6 & 11.9 & 62.8 & 8.66 \\
\hline BR0417_A1_8 & 1128 & 587 & 822 & 1437 & 48.4 & 4.16 & 1005 & 1959 & 330 & 1797 & 415 & 42.9 & 398 & 55.2 & 305 & 56.3 & 143 & 16.8 & 87.9 & 11.6 \\
\hline BR0417_A1_9 & 1318 & 733 & 973 & 973 & 25.9 & 2.59 & 706 & 1701 & 253 & 1241 & 278 & 32.5 & 271 & 36.5 & 208 & 38 & 99 & 11.6 & 61.5 & 8 \\
\hline BR0417_A1_11 & 1335 & 745 & 1013 & 949 & 17.9 & 2.59 & 741 & 1790 & 262 & 1271 & 280 & 31.3 & 271 & 37.3 & 201 & 37.8 & 95.6 & 11.19 & 58.7 & 7.78 \\
\hline BR0417_A1_12 & 1314 & 791 & 994 & 1508 & 34.1 & 5.07 & 1392 & 3290 & 475 & 2168 & 455 & 47.1 & 420 & 56.5 & 314 & 58.6 & 150 & 17.6 & 93.1 & 12.5 \\
\hline BR0417_A1_13 & 1188 & 656 & 896 & 1174 & 16.8 & 2.43 & 862 & 1701 & 275 & 1457 & 322 & 35 & 314 & 43.8 & 242 & 43.3 & 110.6 & 12.6 & 66 & 9.01 \\
\hline BR0417_A1_14 & 1125 & 622 & 866 & 1714 & 53.8 & 4.02 & 1128 & 2033 & 350 & 1944 & 455 & 48.7 & 437 & 60.4 & 335 & 61.4 & 155.4 & 18.1 & 93.8 & 12.86 \\
\hline BR0417_A1_15 & 1267 & 639 & 954 & 1197 & 28.3 & 2.61 & 856 & 1667 & 274.6 & 1458 & 331 & 35 & 324 & 43.7 & 246 & 45.4 & 114.9 & 13.45 & 70.4 & 9.44 \\
\hline BR0417_A1_16 & 1676 & 737 & 950 & 753 & 18.4 & 1.72 & 437 & 780 & 142.8 & 870 & 214.1 & 32.8 & 209 & 28.5 & 158.6 & 28.8 & 73.3 & 8.46 & 42.2 & 5.79 \\
\hline BR0417_A1_17 & 990 & 830 & 1233 & 2097 & 30.6 & 7.29 & 988 & 2481 & 409 & 2123 & 541 & 26.7 & 538 & 81 & 464 & 85.9 & 209 & 23.5 & 117 & 14.8 \\
\hline BR0417_A1_18 & 1379 & 764 & 1012 & 1178 & 23.7 & 4.2 & 878 & 2030 & 304 & 1484 & 345 & 39.7 & 323 & 44.2 & 244 & 46.6 & 120 & 14.1 & 72.7 & 9.85 \\
\hline BR0417_A2__1 & 1185 & 633.1 & 900 & 1143 & 22.1 & 2.34 & 877 & 1681 & 283.1 & 1500 & 329.7 & 34.69 & 308.8 & 42.2 & 236.9 & 43.5 & 108.8 & 12.33 & 64.1 & 8.68 \\
\hline BR0417_A2_2 & 841 & 720 & 808 & 1305 & 25.3 & 2.87 & 1179 & 2950 & 441 & 2034 & 430 & 36.1 & 396 & 52.5 & 294 & 54.4 & 135.1 & 15 & 75.9 & 9.85 \\
\hline BR0417_A2_3 & 921 & 704 & 831 & 1047 & 37.2 & 3.06 & 847 & 2136 & 325 & 1530 & 340 & 37.4 & 310 & 42 & 236 & 43.5 & 110.5 & 12.63 & 64.4 & 8.46 \\
\hline BR0417_A2_4 & 929 & 773 & 883 & 2043 & 28.4 & 3.61 & 1586 & 3316 & 548 & 2834 & 635 & 47.4 & 592 & 80.7 & 456 & 84.9 & 212.9 & 24 & 121.1 & 16.08 \\
\hline BR0417_A2_5 & 939 & 751 & 888 & 1407 & 20.1 & 3.28 & 1260 & 3140 & 470 & 2166 & 471 & 41 & 417 & 57.1 & 315 & 58.2 & 144.8 & 16.2 & 81.1 & 10.64 \\
\hline BR0417_A2_6 & 1261 & 653 & 927 & 1084 & 43.6 & 3.39 & 886 & 2220 & 338 & 1593 & 353 & 40.6 & 323 & 43.7 & 249 & 46.3 & 117.7 & 13.6 & 70.9 & 9.51 \\
\hline BR0417_A2_7 & 1287 & 702 & 993 & 1194 & 29 & 3.65 & 1060 & 2670 & 403 & 1890 & 399 & 37.9 & 391 & 51.5 & 291 & 55.1 & 136 & 15.5 & 78.1 & 10.3 \\
\hline BR0417_A2_8 & 1345 & 712 & 1008 & 1535 & 66 & 5.8 & 1250 & 3180 & 486 & 2260 & 498 & 53.4 & 479 & 64 & 360 & 69.7 & 178 & 20.9 & 109 & 14.7 \\
\hline BR0417_A2_9 & 771 & 844 & 877 & 2103 & 69.7 & 9.47 & 1978 & 3604 & 592 & 3059 & 629 & 65.8 & 563 & 78.1 & 445 & 84.5 & 220.3 & 26.3 & 139 & 18.9 \\
\hline BR0417_A2_10 & 1031 & 636 & 874 & 1416 & 36 & 3.85 & 985 & 1938 & 337 & 1846 & 427 & 47.4 & 413 & 56.8 & 327 & 61.2 & 153.4 & 17.42 & 90.5 & 12.09 \\
\hline
\end{tabular}


Table A1. Cont.

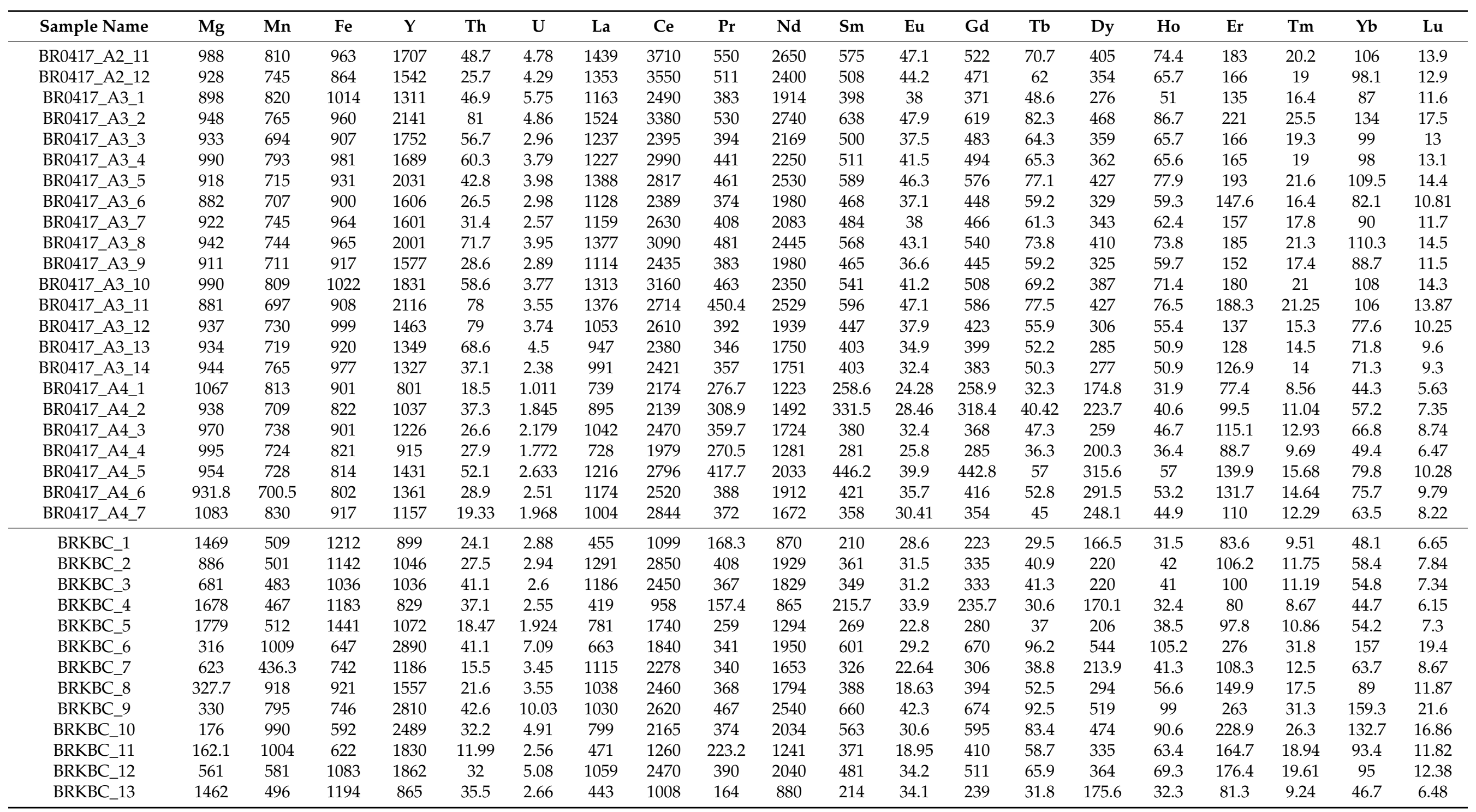




\section{Appendix B}

LA-ICP-MS results of known and unknown Ordovician K-bentonites used for the ML test set.

Table A2. Results from the LA-ICP-MS analyses used as the test set. All elemental abundances are given in ppm.

\begin{tabular}{|c|c|c|c|c|c|c|c|c|c|c|c|c|c|c|c|c|c|c|c|c|}
\hline Sample Name & $\mathrm{Mg}$ & Mn & $\mathrm{Fe}$ & $\mathbf{Y}$ & Th & $\mathbf{U}$ & La & $\mathrm{Ce}$ & $\operatorname{Pr}$ & Nd & $\mathrm{Sm}$ & Eu & Gd & $\mathrm{Tb}$ & Dy & Ho & Er & $\mathrm{Tm}$ & $\mathrm{Yb}$ & $\mathbf{L u}$ \\
\hline FP0417_D_1 & 788 & 454.8 & 909 & 654 & 11.13 & 3.9 & 605 & 1845 & 245 & 1036 & 208.8 & 17.07 & 193.2 & 24.96 & 136.8 & 25.27 & 63.6 & 7.17 & 36.56 & 4.76 \\
\hline FP0417_D_2 & 978 & 412.8 & 921 & 894 & 9.73 & 2.004 & 737 & 2101 & 293 & 1314 & 277.2 & 22.54 & 256.2 & 33.48 & 188.1 & 34.41 & 86.1 & 9.69 & 49.8 & 6.37 \\
\hline FP0417_D_3 & 1339 & 420 & 1245 & 712 & 11.84 & 3.14 & 650 & 2033 & 278.2 & 1180 & 242 & 26.5 & 212.3 & 27.68 & 153.1 & 27.69 & 69.7 & 7.84 & 40.4 & 5.15 \\
\hline FP0417_D_5 & 1290 & 478 & 1232 & 754 & 10.04 & 2.75 & 723 & 2025 & 277.9 & 1210 & 247.4 & 21.35 & 224.2 & 29.2 & 161.1 & 29.5 & 74.1 & 8.48 & 44.3 & 5.7 \\
\hline FP0417_D_6 & 851 & 433 & 1082 & 847 & 7.89 & 2.166 & 703 & 2159 & 292.4 & 1245 & 260.1 & 20.96 & 246.6 & 31.67 & 179 & 32.69 & 81 & 9.1 & 46.7 & 5.98 \\
\hline FP0417_D_7 & 1120 & 381.5 & 1214 & 819 & 11.04 & 2.45 & 613 & 1793 & 253.7 & 1153 & 252.8 & 24.87 & 236.9 & 31.24 & 175.8 & 31.58 & 78.1 & 8.77 & 44 & 5.62 \\
\hline FP0417_D_8 & 724 & 472.4 & 1021 & 486 & 4.3 & 1.194 & 586 & 1621 & 208.3 & 842 & 156.4 & 12.32 & 137.1 & 17.42 & 97.1 & 17.86 & 46 & 5.27 & 28.07 & 3.714 \\
\hline FP0417_D_10 & 1161 & 393.1 & 1146 & 669 & 8.5 & 2.37 & 546.8 & 1645 & 229.1 & 1004 & 213.5 & 23.5 & 200.2 & 25.72 & 142.2 & 25.87 & 64.6 & 7.21 & 36.53 & 4.766 \\
\hline FP0417_D_11 & 1358 & 433.3 & 1312 & 645 & 9.25 & 2.6 & 502.7 & 1473 & 209.4 & 931 & 200.4 & 25.33 & 184.8 & 24.59 & 137.6 & 25.12 & 62.3 & 7.18 & 37 & 4.9 \\
\hline FP0417_D_12 & 1240 & 491.7 & 1156 & 569.8 & 10.1 & 2.224 & 790 & 2252 & 274.9 & 1072 & 189.2 & 15.13 & 162 & 20.23 & 112.4 & 20.88 & 55.1 & 6.57 & 35.55 & 4.77 \\
\hline FP0417_D_13 & 1065 & 456.9 & 1065 & 449.1 & 7.81 & 2.279 & 603 & 1727 & 216.9 & 857 & 152.7 & 21.36 & 136 & 16.93 & 92.2 & 17 & 44.2 & 5.24 & 28.7 & 3.93 \\
\hline FP0417_D_14 & 1259 & 364.4 & 1126 & 938 & 7.09 & 1.852 & 794 & 2228 & 322.8 & 1452 & 315.7 & 19.63 & 287.8 & 37.2 & 205.8 & 36.7 & 87.7 & 9.44 & 47.4 & 5.93 \\
\hline FP0417_D_15 & 1193 & 392.3 & 1303 & 662 & 6.82 & 1.611 & 527.9 & 1550 & 216.3 & 959 & 206.7 & 20.75 & 191.7 & 25.12 & 139.6 & 25.27 & 62.1 & 6.94 & 35.84 & 4.64 \\
\hline FP0417_D_16 & 1247 & 469 & 1383 & 862 & 6.33 & 4.37 & 539 & 1727 & 238 & 1041 & 237.7 & 13.91 & 234.8 & 32.7 & 189.2 & 34.9 & 87.7 & 10.03 & 51.4 & 6.53 \\
\hline BGX_1 & 1143 & 902 & 1565 & 1320 & 44.1 & 6.04 & 1435 & 4170 & 592 & 2640 & 537 & 21.59 & 454 & 53 & 296 & 54.5 & 136.6 & 15.04 & 78 & 10.14 \\
\hline BGX_2 & 1207 & 693 & 1318 & 1158 & 53.3 & 4.71 & 1256 & 3527 & 531 & 2417 & 478 & 16.23 & 408 & 48.7 & 261.7 & 46.4 & 116.8 & 12.75 & 64.8 & 8.32 \\
\hline BGX_4 & 1276 & 1065 & 1930 & 1530 & 54.7 & 6.3 & 1324 & 4280 & 637 & 2840 & 583 & 19.9 & 534 & 62.5 & 349 & 62.7 & 158 & 17.8 & 88.3 & 11.37 \\
\hline BGX_5 & 1462 & 1387 & 2100 & 2102 & 48.2 & 6.65 & 1038 & 3330 & 499 & 2272 & 542 & 16.48 & 517 & 71.5 & 420 & 80 & 212 & 25.1 & 131.9 & 17.11 \\
\hline BGX_6 & 1178 & 1123 & 1857 & 1540 & 44.9 & 3.85 & 1114 & 3560 & 540 & 2369 & 533 & 18.83 & 476 & 59.1 & 325 & 57.9 & 144.9 & 16.3 & 84.4 & 10.91 \\
\hline BGX_7 & 1618 & 1365 & 2119 & 2674 & 39.3 & 8.57 & 939 & 2854 & 478 & 2283 & 603 & 17.02 & 604 & 91.2 & 560 & 109.5 & 291 & 34.1 & 177.3 & 23 \\
\hline BGX_8 & 1465 & 1189 & 1990 & 1884 & 36.1 & 8.26 & 896 & 2939 & 455 & 2103 & 530 & 15.64 & 500 & 68.5 & 400 & 73.8 & 193.8 & 22.51 & 118.3 & 15.26 \\
\hline BGX_9 & 1759 & 1146 & 2026 & 1814 & 65.8 & 5.93 & 970 & 3067 & 488 & 2284 & 552 & 18.3 & 511 & 68.9 & 398 & 73.1 & 184.9 & 21.6 & 112.4 & 14.2 \\
\hline BGX_10 & 1452 & 1547 & 2219 & 2623 & 60.2 & 6.13 & 816 & 2800 & 458 & 2151 & 596 & 19.14 & 605 & 88.6 & 528 & 97.7 & 254 & 29.1 & 156.5 & 19.3 \\
\hline BGX_11 & 1279 & 1181 & 1646 & 1916 & 29.4 & 3.98 & 909 & 2860 & 449 & 2075 & 509 & 17.66 & 476 & 68.2 & 402 & 73.9 & 190 & 22.3 & 116.3 & 14.77 \\
\hline BGX_12 & 1365 & 1976 & 2281 & 3159 & 65.6 & 12.84 & 828 & 2940 & 471 & 2253 & 674 & 19.4 & 685 & 107.3 & 663 & 125.9 & 320 & 36.2 & 181 & 21.6 \\
\hline BGX_13 & 1469 & 1352 & 1931 & 2666 & 60.7 & 6.38 & 697 & 2122 & 360 & 1867 & 558 & 18.39 & 576 & 90 & 552 & 107.5 & 281 & 33.9 & 178.7 & 23 \\
\hline RMKB_16_1 & 737 & 452 & 976 & 774 & 7.47 & 1.92 & 726 & 2221 & 291.1 & 1232 & 249.9 & 19.32 & 229.6 & 29.57 & 165.7 & 30.4 & 75.6 & 8.61 & 43.8 & 5.73 \\
\hline
\end{tabular}


Table A2. Cont.

\begin{tabular}{|c|c|c|c|c|c|c|c|c|c|c|c|c|c|c|c|c|c|c|c|c|}
\hline Sample Name & $\mathrm{Mg}$ & Mn & $\mathrm{Fe}$ & $\mathbf{Y}$ & Th & $\mathbf{U}$ & La & $\mathrm{Ce}$ & Pr & $\mathrm{Nd}$ & Sm & Eu & Gd & $\mathbf{T b}$ & Dy & Ho & Er & $\mathrm{Tm}$ & $\mathbf{Y b}$ & Lu \\
\hline RMKB_16_2 & 638 & 500.1 & 880 & 498.4 & 8.53 & 1.601 & 728 & 2059 & 254.5 & 978 & 168.4 & 12.57 & 147.3 & 18.25 & 100.5 & 18.85 & 49.2 & 5.76 & 31.1 & 4.14 \\
\hline RMKB_16_3 & 835 & 436 & 933 & 593 & 3.8 & 1.17 & 528 & 1613 & 215.4 & 915 & 187.1 & 15.24 & 170.7 & 22.46 & 125.1 & 22.94 & 57.1 & 6.37 & 33 & 4.22 \\
\hline RMKB_16_4 & 864 & 431.1 & 1149 & 810 & 7.45 & 2.041 & 680 & 2126 & 284.6 & 1214 & 252.7 & 20.6 & 235.7 & 30.3 & 170.2 & 31.06 & 77.2 & 8.72 & 44.7 & 5.79 \\
\hline RMKB_16_6 & 718 & 456.3 & 972 & 690 & 6.84 & 11.3 & 650 & 1929 & 253 & 1087 & 224 & 17.63 & 207.8 & 27.09 & 151.6 & 27.98 & 69.2 & 7.65 & 38.9 & 5.02 \\
\hline RMKB_16_7 & 1030 & 471 & 1011 & 903 & 10.95 & 2.75 & 783 & 2500 & 327.4 & 1355 & 282 & 23.58 & 262 & 33.8 & 192.6 & 35.1 & 88.3 & 10.09 & 51.6 & 6.57 \\
\hline RMKB_16_8 & 940 & 431.7 & 962 & 774 & 10.18 & 2.7 & 644 & 1966 & 263.1 & 1124 & 236.9 & 21.44 & 214 & 28.01 & 158 & 28.99 & 73.4 & 8.42 & 43.6 & 5.62 \\
\hline RMKB_16_9 & 852 & 435 & 948 & 721 & 7.11 & 2.12 & 636 & 2026 & 269.2 & 1131 & 233.3 & 19.03 & 208.5 & 27.52 & 154.7 & 28.1 & 70.3 & 7.92 & 40.2 & 5.27 \\
\hline RMKB_16_11 & 866 & 457.3 & 927 & 565 & 7.16 & 1.904 & 431.4 & 1358 & 185.6 & 800 & 170.7 & 22.06 & 156.5 & 20.66 & 115.4 & 21.13 & 52.4 & 6.11 & 32.15 & 4.16 \\
\hline RMKB_16_12 & 850 & 426.9 & 900 & 888 & 10.37 & 2.26 & 723 & 2193 & 295.8 & 1298 & 268.4 & 21.65 & 251.5 & 33.6 & 185.9 & 33.9 & 84 & 9.47 & 48.8 & 6.25 \\
\hline RMKB_16_13 & 816 & 433.5 & 938 & 759 & 6.27 & 1.399 & 640 & 1929 & 258.7 & 1103 & 234.4 & 19 & 215 & 28.02 & 159.1 & 29.05 & 73.2 & 8.22 & 42.2 & 5.37 \\
\hline RMKB_16_14 & 778 & 464 & 925 & 635 & 7.64 & 2.23 & 628 & 1976 & 254.1 & 1001 & 198.8 & 18.02 & 181.1 & 23.22 & 132.4 & 24.23 & 61.2 & 7.05 & 36.7 & 4.75 \\
\hline RMKB_16_15 & 830 & 413 & 894 & 540 & 3.48 & 0.873 & 477 & 1479 & 191.8 & 816 & 166.7 & 14.32 & 151.7 & 19.55 & 112.4 & 20.27 & 49.9 & 5.61 & 28.8 & 3.65 \\
\hline RMKB_16_16 & 865 & 448 & 1124 & 805 & 9.29 & 2.39 & 721 & 2216 & 297.7 & 1255 & 257.7 & 19.95 & 231.6 & 30.44 & 168.9 & 31.1 & 77.4 & 8.85 & 45.9 & 5.85 \\
\hline RMMNE_1 & 188.8 & 795 & 625 & 1305 & 11.27 & 2.62 & 431.8 & 1253 & 214.5 & 1136 & 318.3 & 19.75 & 333 & 46.96 & 273.9 & 50.3 & 126.1 & 14.36 & 72.9 & 9.26 \\
\hline RMMNE_2 & 194.8 & 810 & 649 & 1132 & 6.42 & 1.736 & 401.6 & 1205 & 199 & 1017 & 279.7 & 18.66 & 286.6 & 40.1 & 235.6 & 43.09 & 108 & 12.38 & 62.1 & 7.91 \\
\hline RMMNE_5 & 208.9 & 871 & 729 & 1324 & 10.16 & 2.887 & 434.1 & 1427 & 234.5 & 1175 & 331.3 & 19.98 & 338.3 & 47.78 & 280.8 & 51.94 & 129.6 & 14.72 & 74.2 & 9.49 \\
\hline RMMNE_6 & 200 & 836 & 668 & 1528 & 12.7 & 3.51 & 537.4 & 1703 & 278.8 & 1401 & 376.9 & 23.55 & 383.6 & 54.9 & 320.6 & 58.8 & 147.5 & 16.9 & 85.9 & 10.91 \\
\hline RMMNE_7 & 191.8 & 810 & 642 & 1398 & 10.3 & 2.447 & 486.4 & 1458 & 247.5 & 1284 & 350.4 & 21.13 & 355.4 & 50.2 & 293.4 & 54.6 & 136.1 & 15.68 & 79.1 & 10.05 \\
\hline RMMNE_8 & 267.7 & 897 & 813 & 1387 & 13.09 & 3.471 & 578 & 1653 & 265.2 & 1337 & 355.8 & 22.78 & 362.1 & 50.95 & 296.7 & 54.8 & 136.7 & 15.56 & 79 & 10.09 \\
\hline RMMNE_9 & 204.3 & 863 & 720 & 1509 & 11.44 & 3.681 & 484.2 & 1641 & 264.6 & 1317 & 374.6 & 22.78 & 387.5 & 55.39 & 323.3 & 59.38 & 147.7 & 16.78 & 84.7 & 10.76 \\
\hline RMMNE_10 & 192.1 & 807.8 & 659 & 1966 & 19.66 & 4.87 & 577 & 1729 & 302.7 & 1596 & 469 & 28.22 & 488 & 70.3 & 415 & 77 & 191.1 & 21.98 & 110.8 & 14.01 \\
\hline RMMNE_11 & 197.3 & 834 & 685 & 1524 & 15.1 & 3.492 & 541.9 & 1647 & 273.4 & 1394 & 376.9 & 23.88 & 384.3 & 54.4 & 317.2 & 58 & 145.1 & 16.71 & 85 & 10.78 \\
\hline RMMNE_12 & 203.6 & 845 & 767 & 1390 & 9.85 & 3.079 & 453.8 & 1514 & 243.1 & 1235 & 345 & 20.9 & 352 & 50.53 & 294.9 & 54.37 & 135.7 & 15.4 & 77.8 & 9.89 \\
\hline RMMNE_13 & 197.3 & 841 & 679 & 1275 & 10.29 & 2.758 & 409 & 1359 & 218.1 & 1105 & 312.6 & 20 & 320.1 & 46.18 & 270.2 & 49.47 & 122.5 & 13.97 & 70.4 & 8.94 \\
\hline RMMNE_14 & 203.8 & 857 & 702 & 1261 & 8.95 & 2.602 & 424.4 & 1420 & 226.2 & 1131 & 317.2 & 19.59 & 318.9 & 45.59 & 266.3 & 49.16 & 123.7 & 14.21 & 71.3 & 8.99 \\
\hline RMMNE_15 & 1225 & 446.7 & 1277 & 1010 & 13.77 & 2.8 & 639.4 & 1587 & 255.5 & 1272 & 294.6 & 31.33 & 282.3 & 38.05 & 214.1 & 38.91 & 96.4 & 10.98 & 55.9 & 7.32 \\
\hline RMMNE_16 & 222 & 805.4 & 693 & 1635 & 32.7 & 3.83 & 485.5 & 1470 & 251.4 & 1337 & 391.4 & 23.81 & 410.5 & 59 & 346.5 & 63.9 & 158.4 & 17.97 & 89.9 & 11.39 \\
\hline RMMNE_17 & 194.4 & 819 & 900 & 1334 & 10.01 & 2.663 & 410.8 & 1325 & 219.9 & 1138 & 323.1 & 20.35 & 340.8 & 48.06 & 282.9 & 52.2 & 129 & 14.65 & 73.4 & 9.32 \\
\hline RMMNE_18 & 192.8 & 816.8 & 693 & 1872 & 23.1 & 4.5 & 567 & 1729 & 296.2 & 1545 & 451 & 26.67 & 466 & 66.9 & 393 & 72.4 & 180.9 & 20.61 & 104.3 & 13.28 \\
\hline RMMNE_19 & 188.3 & 797 & 625 & 1742 & 17.85 & 4.36 & 555.6 & 1610 & 281 & 1491 & 423.7 & 25.72 & 432.1 & 62.3 & 366.1 & 68 & 170.3 & 19.57 & 99.7 & 12.65 \\
\hline SPMBD_1 & 837 & 456 & 1006 & 1005 & 14.3 & 3.3 & 866 & 2710 & 360 & 1531 & 322 & 26.6 & 298 & 38.2 & 215.4 & 39.6 & 99.3 & 11.37 & 58.2 & 7.47 \\
\hline SPMBD_2 & 884 & 447 & 1027 & 740 & 6.74 & 1.81 & 636 & 1947 & 259.1 & 1105 & 236.2 & 19.03 & 211.6 & 28 & 156.5 & 28.7 & 72.2 & 8.17 & 41.5 & 5.38 \\
\hline
\end{tabular}


Table A2. Cont.

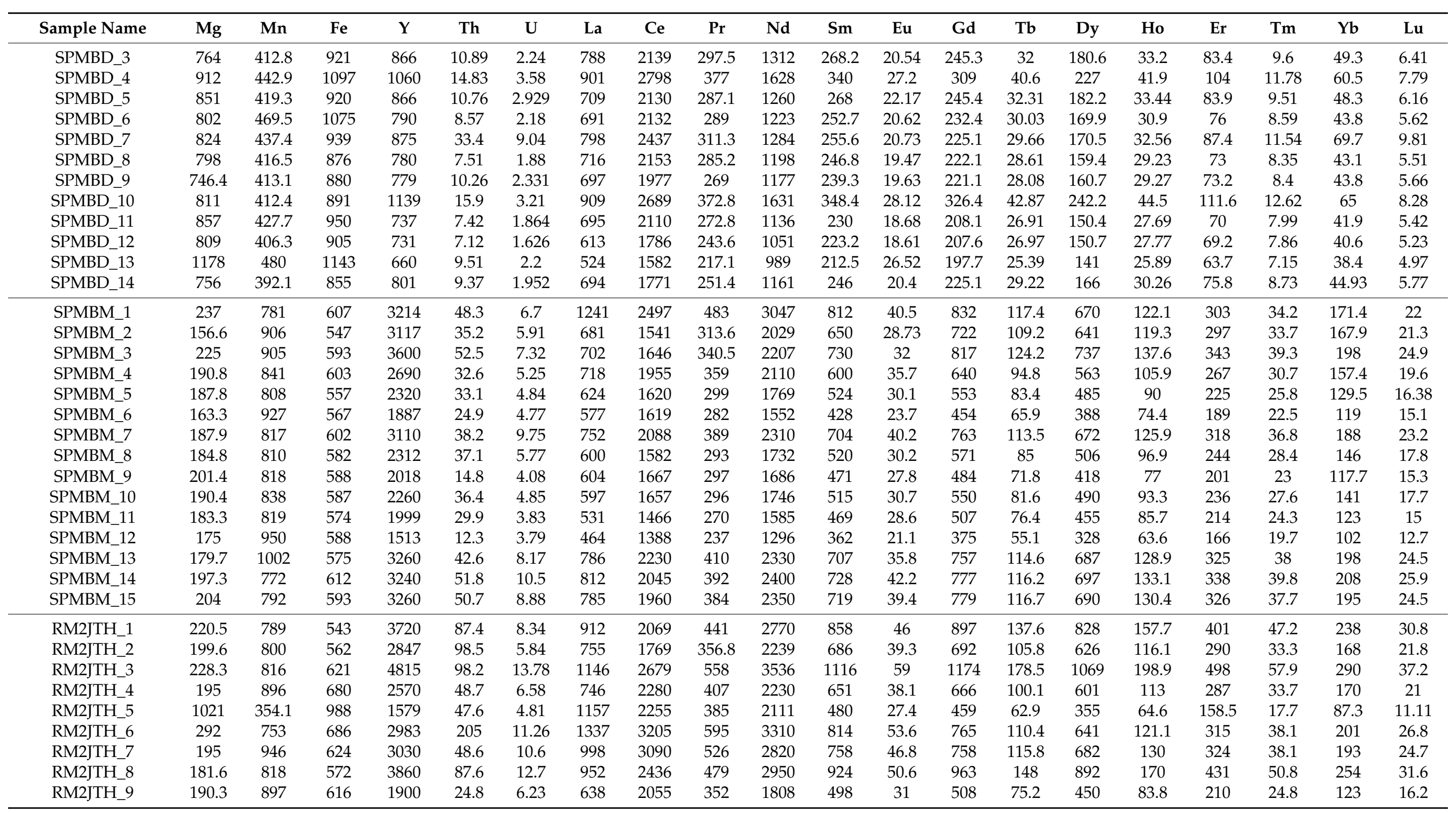


Table A2. Cont.

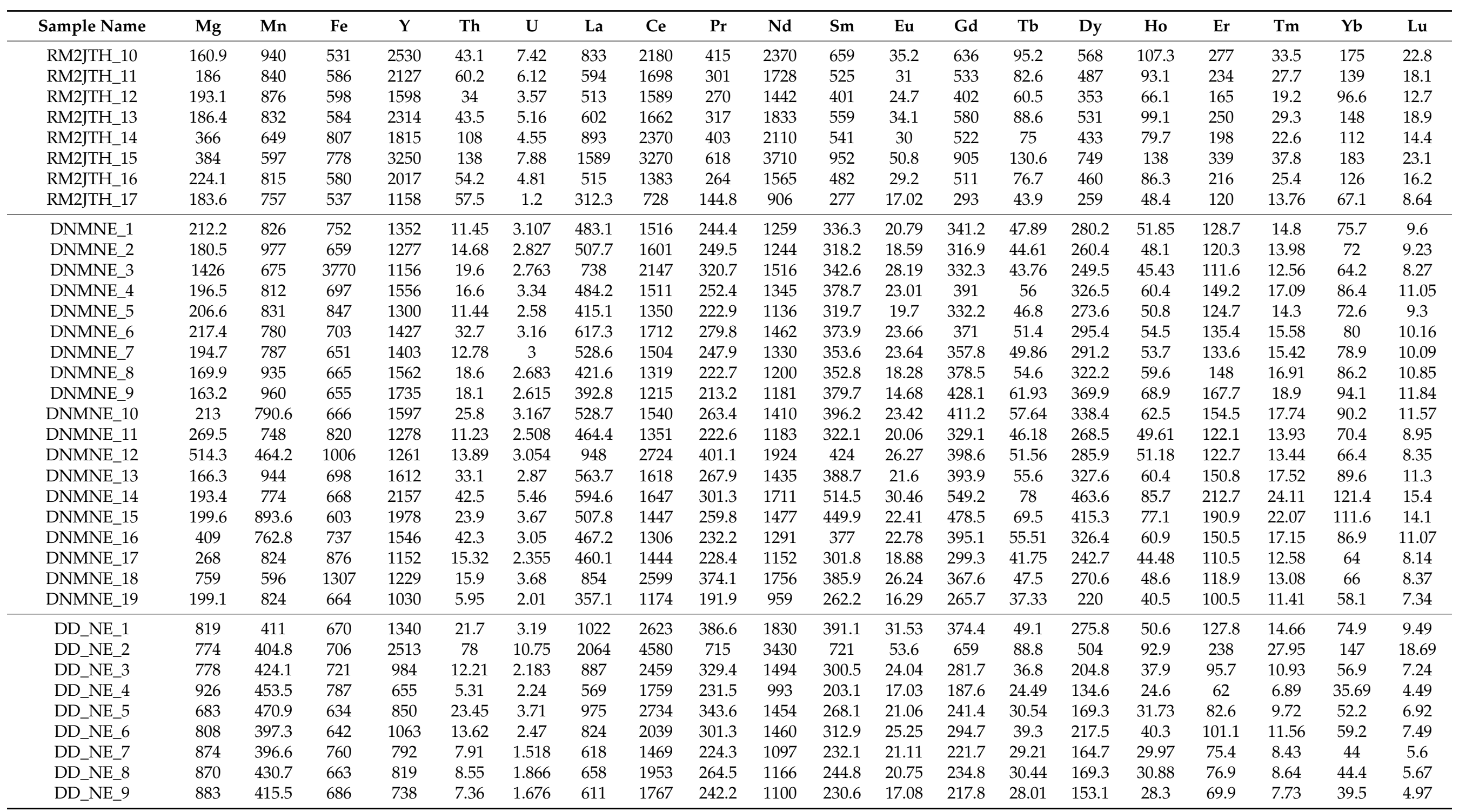


Table A2. Cont.

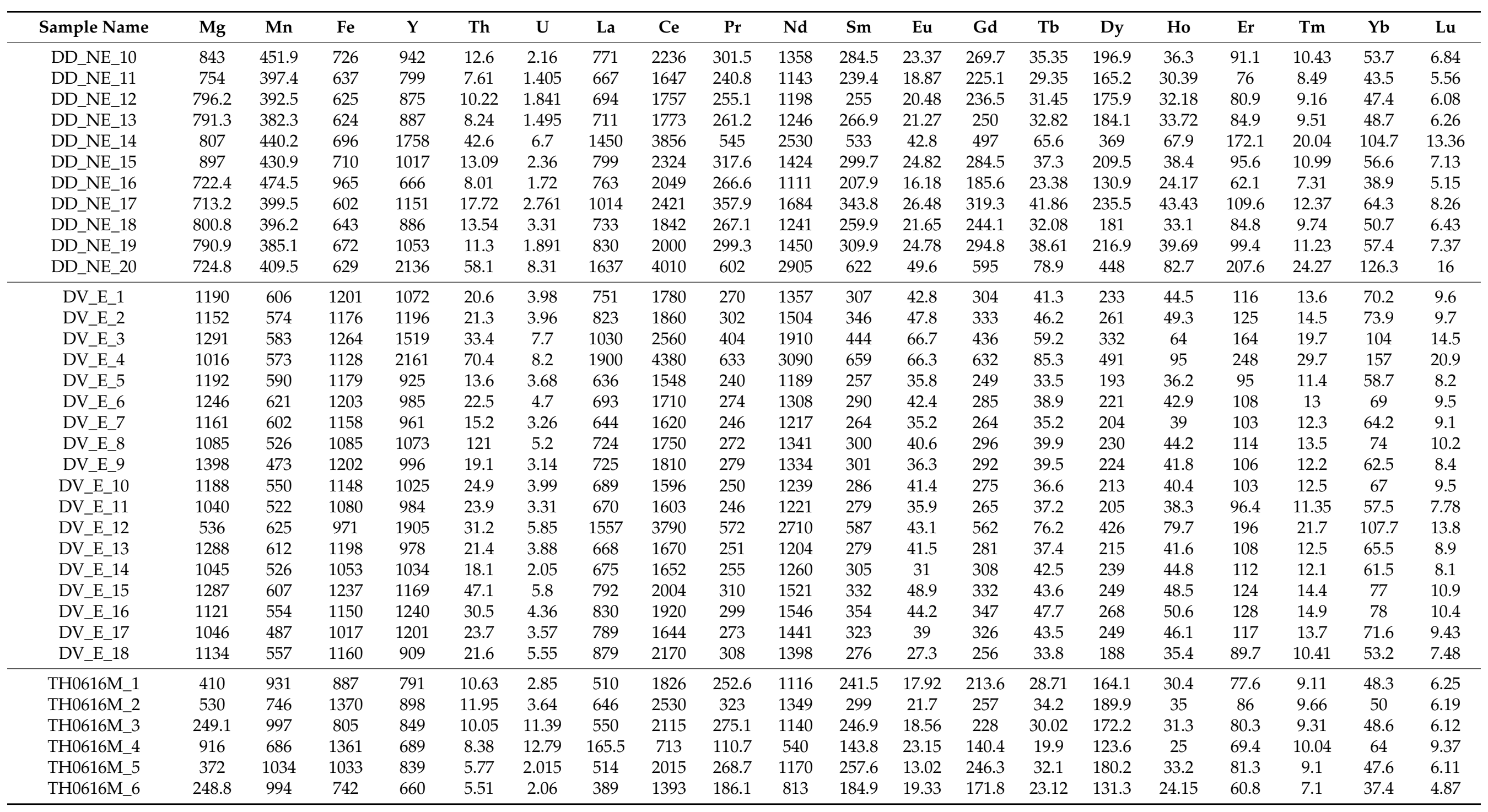


Table A2. Cont.

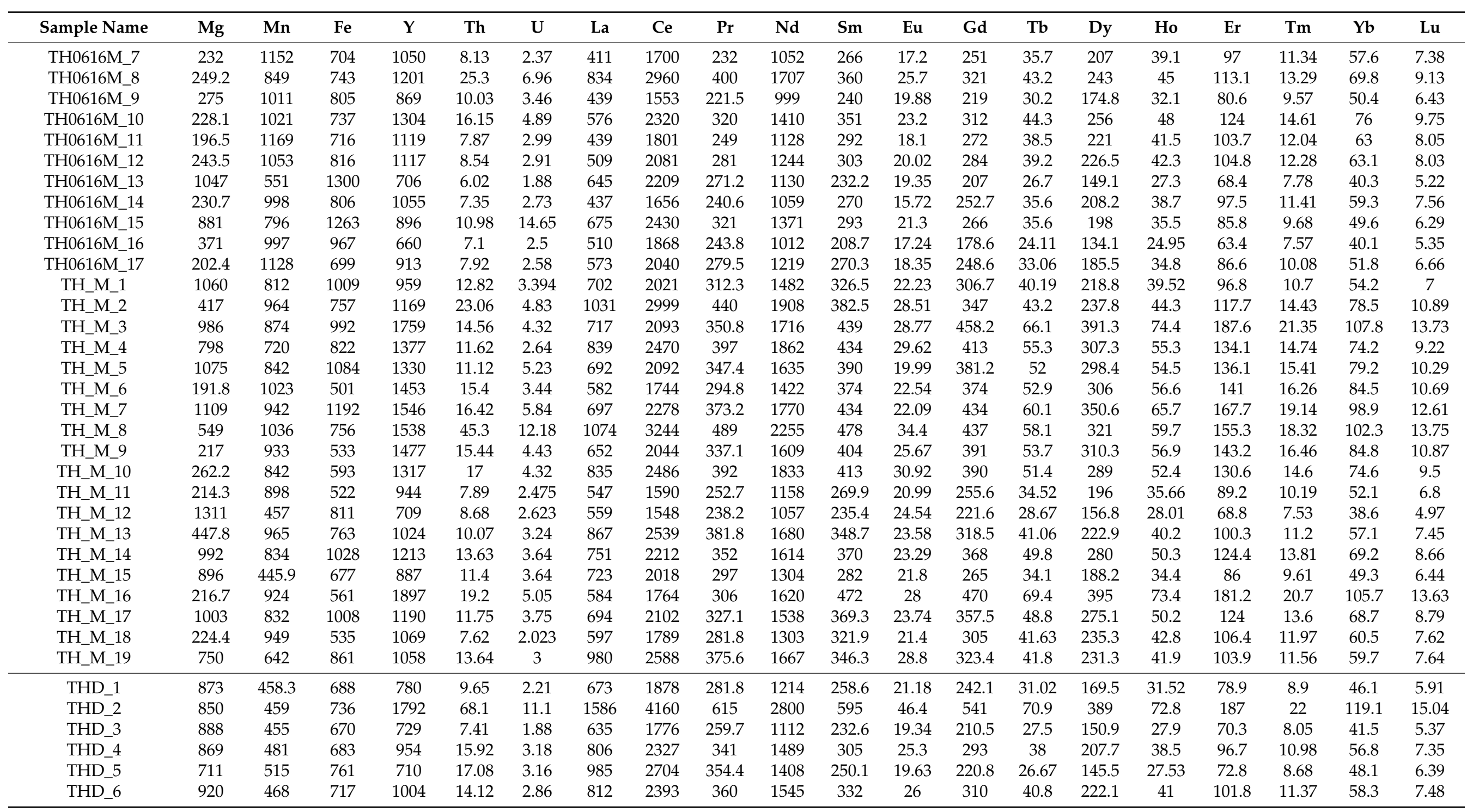


Table A2. Cont.

\begin{tabular}{|c|c|c|c|c|c|c|c|c|c|c|c|c|c|c|c|c|c|c|c|c|}
\hline Sample Name & $\mathrm{Mg}$ & Mn & $\mathrm{Fe}$ & $\mathbf{Y}$ & Th & $\mathbf{U}$ & $\mathbf{L a}$ & $\mathrm{Ce}$ & Pr & $\mathrm{Nd}$ & Sm & $\mathbf{E u}$ & Gd & $\mathbf{T b}$ & Dy & Ho & Er & $\operatorname{Tm}$ & $\mathbf{Y b}$ & Lu \\
\hline THD_7 & 892 & 451.7 & 670 & 970 & 14.71 & 3.63 & 807 & 2350 & 338 & 1489 & 313.7 & 25.61 & 300.5 & 38.8 & 212.4 & 39.5 & 98.3 & 11.05 & 57.4 & 7.39 \\
\hline THD_8 & 852 & 461.3 & 653 & 964 & 12.49 & 4.57 & 824 & 2395 & 350 & 1534 & 319 & 24.65 & 297 & 38.1 & 209.7 & 38.8 & 97.9 & 10.96 & 56.5 & 7.35 \\
\hline THD_9 & 748 & 478 & 648 & 993 & 18.57 & 3.81 & 975 & 2787 & 400 & 1675 & 330.6 & 25.52 & 309.6 & 39.3 & 215.7 & 40.4 & 102.4 & 11.67 & 62.2 & 8.17 \\
\hline THD_10 & 800 & 469.2 & 678 & 937 & 10.83 & 1.978 & 830 & 2153 & 326.5 & 1462 & 308.4 & 24.65 & 287.7 & 37.16 & 203.7 & 38 & 95.1 & 10.81 & 56.8 & 7.39 \\
\hline THD_11 & 868 & 445.5 & 682 & 1001 & 18.29 & 3.23 & 932 & 2674 & 380.4 & 1628 & 330.9 & 26.37 & 302.9 & 38.97 & 215 & 40.2 & 100.7 & 11.61 & 60.7 & 7.85 \\
\hline THD_12 & 872 & 503 & 709 & 957 & 10.54 & 2.41 & 818 & 2356 & 345.7 & 1498 & 312 & 25.36 & 299.4 & 38 & 209.8 & 39.2 & 96.9 & 10.98 & 56.4 & 7.28 \\
\hline THD_13 & 839 & 465 & 673 & 842 & 17.28 & 4.08 & 814 & 2332 & 334.1 & 1408 & 284.5 & 23.02 & 263 & 33.6 & 182.2 & 33.9 & 85.3 & 9.65 & 50.5 & 6.45 \\
\hline
\end{tabular}




\section{Appendix C}

LA-ICP-MS settings for the different runs.

Table A3. Big Ridge Kb-A (laser runs A1-A3), Big Ridge Kb-B (laser runs B1-B3), Big Ridge Kb-C, Rochester Millbrig and Deicke, Brickyard Millbrig, Dickeyville Elkport.

\begin{tabular}{|c|c|c|}
\hline Instrument & Parameters & Setting \\
\hline \multicolumn{3}{|c|}{ Thermo Scientific iCap Qc ICP-MS } \\
\hline & RF Power $(W)$ & 1550 \\
\hline & Cool gas flow rate $(\mathrm{mL} / \mathrm{min})$ & 1400 \\
\hline & Carrier gas (Ar) flow rate $(\mathrm{mL} / \mathrm{min})$ & 723 \\
\hline & Carrier gas $(\mathrm{He})$ flow rate $(\mathrm{mL} / \mathrm{min})$ & 700 \\
\hline \multicolumn{3}{|c|}{ Cetac G2 LSX-213 Laser Ablation System } \\
\hline & Laser type & Nd: YAG \\
\hline & Wavelength (nm) & 213 \\
\hline & Laser energy $(\%)$ & 30 \\
\hline & Pulse repetition rate $(\mathrm{Hz})$ & 10 \\
\hline & Shutter delay (s) & 10 \\
\hline & Burst count & 800 \\
\hline & Ablation time (s) & 90 \\
\hline & Washout time (s) & 30 \\
\hline & Spot size $(\mu \mathrm{m})$ & 25 \\
\hline
\end{tabular}

Table A4. Big Ridge Kb-A A4, Big Ridge Millbrig M1-M4, Big Ridge Deicke D1-D7, Brickyard Deicke, Decorah Deicke, Fort Payne Deicke and Millbrig, Tidwell Hollow Millbrig, Dickeyville Millbrig.

\begin{tabular}{ccc}
\hline \multicolumn{1}{c}{ Parameters } & Setting \\
\hline Instrument & \multicolumn{1}{c}{ Thermo Scientific iCap Qc ICP-MS } & 1550 \\
& RF Power (W) & 1400 \\
Cool gas flow rate $(\mathrm{mL} / \mathrm{min})$ & 723 \\
& Carrier gas (Ar) flow rate $(\mathrm{mL} / \mathrm{min})$ & 650 \\
& Carrier gas (He) flow rate $(\mathrm{mL} / \mathrm{min})$ & \\
& & Nd: YAG \\
Cetac G2 LSX-213 Laser Ablation System & 213 \\
Laser type & 30 \\
Wavelength $(\mathrm{nm})$ & 10 \\
Laser energy $(\%)$ & 10 \\
Pulse repetition rate $(\mathrm{Hz})$ & 600 \\
Shutter delay $(\mathrm{s})$ & 60 \\
Burst count & 30 \\
Ablation time $(\mathrm{s})$ & 50 \\
Washout time $(\mathrm{s})$ & \\
Spot size $(\mu \mathrm{m})$ &
\end{tabular}

Table A5. Fort Payne Millbig Bottom, Bruton Gap Kb-X, Tidwell Hollow Deicke.

\begin{tabular}{|c|c|c|}
\hline Instrument & Parameters & Setting \\
\hline \multicolumn{3}{|c|}{ Thermo Scientific iCap Qc ICP-MS } \\
\hline & RF Power $(W)$ & 1550 \\
\hline & Cool gas flow rate $(\mathrm{mL} / \mathrm{min})$ & 1400 \\
\hline & Carrier gas (Ar) flow rate $(\mathrm{mL} / \mathrm{min})$ & 723 \\
\hline & Carrier gas $(\mathrm{He})$ flow rate $(\mathrm{mL} / \mathrm{min})$ & 800 \\
\hline \multicolumn{3}{|c|}{ Cetac G2 LSX-213 Laser Ablation System } \\
\hline & Laser type & Nd: YAG \\
\hline & Wavelength (nm) & 213 \\
\hline & Laser energy $(\%)$ & 30 \\
\hline & Pulse repetition rate $(\mathrm{Hz})$ & 10 \\
\hline & Shutter delay (s) & 10 \\
\hline & Burst count & 700 \\
\hline & Ablation time (s) & 60 \\
\hline & Washout time (s) & 30 \\
\hline & Spot size $(\mu \mathrm{m})$ & 50 \\
\hline
\end{tabular}




\section{References}

1. Mao, M.; Rukhlov, A.S.; Rowins, S.M.; Spence, J.; Coogan, L.A. Apatite Trace Element Compositions: A Robust New Tool for Mineral Exploration. Econ. Geol. 2016, 111, 1187-1222. [CrossRef]

2. O'Sullivan, G.; Chew, D.; Kenny, G.; Henrichs, I.; Mulligan, D. The trace element composition of apatite and its application to detrital provenance studies. Earth Sci. Rev. 2020, 201, 103044. [CrossRef]

3. Takashima, R.; Kusakawa, H.; Kuwabara, S.; Orihashi, Y.; Nishi, H.; Niwano, M.; Yoshida, T. Identification of the source caldera for a Pliocene ash-flow tuff in Northeast Japan based on apatite trace-element compositions and zircon U-Pb ages. J. Volcanol. Geotherm. Res. 2020, 401, 106948. [CrossRef]

4. Sell, K.B.; Samson, S.D. A tephrochronologic method based on apatite trace-element chemistry. Quat. Res. 2017, 76, 157-166. [CrossRef]

5. Sell, B.K.; Samson, S.D.; Mitchell, C.E.; McLaughlin, P.I.; Koenig, A.E.; Leslie, S.A. Stratigraphic correlations using trace elements in apatite from Late Ordovician (Sandbian-Katian) K-bentonites of eastern North America. Geol. Soc. Am. Bull. 2015, 127, 1259-1274. [CrossRef]

6. Takashima, R.; Kuwabara, S.; Sato, T.; Takemura, K.; Nishi, H. Utility of trace elements in apatite for discrimination and correlation of Quaternary ignimbrites and co-ignimbrite ashes, Japan. Quat. Geochronol. 2017, 41, 151-162. [CrossRef]

7. Kolata, D.R.; Huff, W.D.; Bergström, S.M. Ordovician K-Bentonites of Eastern North America; Geological Society of America: Boulder, CO, USA, 1996; Volume 313.

8. Huff, W.D. Ordovician K-bentonites: Issues in interpreting and correlating ancient tephras. Quat. Int. 2008, 178, 276-287. [CrossRef]

9. Huff, W.D.; Kolata, D.R. Correlation of the Ordovician Deicke and Millbrig K-Bentonites Between the Mississippi Valley and the Southern Appalachians (1). AAPG Bull. 1990, 74, 1736-1747. [CrossRef]

10. Bergström, S.M.; Huff, W.D.; Kolata, D.R.; Bauert, H. Nomenclature, stratigraphy, chemical fingerprinting, and areal distribution of some Middle Ordovician K-bentonites in Baltoscandia. Gff 1995, 117, 1-13. [CrossRef]

11. Dronov, A.; Huff, W.; Kanygin, A.; Gonta, T. K-bentonites in the Upper Ordovician of the Siberian Platform. Ordovician World. Cuad. Del Mus. Geomin. 2011, 14, 135-141.

12. Fanning, C.M.; Pankhurst, R.J.; Rapela, C.W.; Baldo, E.G.; Casquet, C.; Galindo, C. K-bentonites in the Argentine Precordillera contemporaneous with rhyolite volcanism in the Famatinian Arc. J. Geol. Soc. 2004, 161, 747-756. [CrossRef]

13. Lowe, D.J. Tephrochronology and its application: A review. Quat. Geochronol. 2011, 6, 107-153. [CrossRef]

14. Carey, A.; Samson, S.D.; Sell, B. Utility and Limitations of Apatite Phenocryst Chemistry for Continent-Scale Correlation of Ordovician K-Bentonites. J. Geol. 2009, 117, 1-14. [CrossRef]

15. Emerson, N.R.; Simo, J.A.; Byers, C.W.; Fournelle, J. Correlation of (Ordovician, Mohawkian) K-bentonites in the upper Mississippi valley using apatite chemistry: Implications for stratigraphic interpretation of the mixed carbonate-siliciclastic Decorah Formation. Palaeogeogr. Palaeoclimatol. Palaeoecol. 2004, 210, 215-233. [CrossRef]

16. Kolata, D.R.; Huff, W.D.; Bergström, S.M. Nature and regional significance of unconformities associated with the Middle Ordovician Hagan K-bentonite complex in the North American midcontinent. Geol. Soc. Am. Bull. 1998, 110, 723-739. [CrossRef]

17. Bolton, M.S.M.; Jensen, B.J.L.; Wallace, K.; Praet, N.; Fortin, D.; Kaufman, D.; De Batist, M. Machine learning classifiers for attributing tephra to source volcanoes: An evaluation of methods for Alaska tephras. J. Quat. Sci. 2019, 35, 81-92. [CrossRef]

18. Carniel, R.; Guzmán, S.R. Machine Learning in Volcanology: A Review. In Updates in Volcanology-Transdisciplinary Nature of Volcano Science. Nemeth, K., Ed.; IntechOpen: London, UK, 2020. [CrossRef]

19. Rosenau, N.A.; Herrmann, A.D.; Leslie, S.A. Conodont apatite $\delta 18 \mathrm{O}$ values from a platform margin setting, Oklahoma, USA: Implications for initiation of Late Ordovician icehouse conditions. Palaeogeogr. Palaeoclimatol. Palaeoecol. 2012, 315, $172-180$. [CrossRef]

20. Quinton, P.C.; Herrmann, A.D.; Leslie, S.A.; MacLeod, K.G. Carbon cycling across the southern margin of Laurentia during the Late Ordovician. Palaeogeogr. Palaeoclimatol. Palaeoecol. 2016, 458, 63-76. [CrossRef]

21. Quinton, P.C.; Law, S.; Macleod, K.G.; Herrmann, A.D.; Haynes, J.T.; Leslie, S.A. Testing the early Late Ordovician cool-water hypothesis with oxygen isotopes from conodont apatite. Geol. Mag. 2017, 155, 1727-1741. [CrossRef]

22. Keller, M.; Lehnert, O. Ordovician paleokarst and quartz sand: Evidence of volcanically triggered extreme climates? Palaeogeogr. Palaeoclimatol. Palaeoecol. 2010, 296, 297-309. [CrossRef]

23. Hall, M.; Frank, E.; Holmes, G.; Pfahringer, B.; Reutemann, P.; Witten, I.H. The WEKA data mining software: An update. ACM SIGKDD Explor. Newsl. 2009, 11, 10-18. [CrossRef]

24. Witten, I.H.; Frank, E. Data mining: Practical machine learning tools and techniques with Java implementations. ACM Sigmod Rec. 2002, 31, 76-77. [CrossRef]

25. Valls, R.A. Exploring Geological Data with Weka, CoDaPack, and iNZight: Graphical Instructions; CreateSpace Independent Publishing Platform: Scotts Valley, CA, USA, 2017.

26. Quinlan, J.R. C4. 5: Programs for Machine Learning; Elsevier: Amsterdam, The Netherlands, 2014.

27. Herrmann, A.D.; Haynes, J.T.; Robinet, R.M.; Konzett, J.; Emerson, N.R. Insights into the tectonostratigraphic setting of the Southern Appalachians during the Blountian tectophase from an integrated geochemical analysis of magmatic phenocrysts in the Ordovician Deicke K-bentonite. Lithos 2021, 398-399, 106301. [CrossRef] 
28. Rice, W.F. The Systematics and Biostratigraphy of the Brachiopoda of the Decorah Shale at St. Paul, Minnesota; University of Minnesota: Minneapolis, MN, USA, 1985.

29. Herrmann, A.; Haynes, J.T. Ordovician of the Southern Appalachians, USA, Pre-symposium Field Trip. Stratigraphy 2015, $12,203-251$.

30. Haynes, J.T. The Ordovician Deicke and Millbrig K-Bentonite Beds of the Cincinnati Arch and the Southern Valley and Ridge Province; Geological Society of America: Boulder, CO, USA, 1994; Volume 290.

31. Paton, C.; Hellstrom, J.; Paul, B.; Woodhead, J.; Hergt, J. Iolite: Freeware for the visualisation and processing of mass spectrometric data. J. Anal. At. Spectrom. 2011, 26, 2508-2518. [CrossRef]

32. Schmitt, R.A.; Smith, R.H.; Lasch, J.E.; Mosen, A.W.; Olehy, D.A.; Vasilevskis, J. Abundances of the fourteen rare-earth elements, scandium, and yttrium in meteoritic and terrestrial matter. Geochim. Cosmochim. Acta 1963, 27, 577-622. [CrossRef]

33. Stormer, J.C.; Pierson, M.L.; Tacker, R.C. Variation of F and $\mathrm{Cl}$ X-ray intensity due to anisotropic diffusion in apatite during electron microprobe analysis. Am. Mineral. 1993, 78, 641-648.

34. Flemetakis, S.; Berndt, J.; Klemme, S.; Genske, F.; Cadoux, A.; Louvel, M.; Rohrbach, A. An Improved Electron Microprobe Method for the Analysis of Halogens in Natural Silicate Glasses. Microsc. Microanal. 2020, 26, 857-866. [CrossRef] [PubMed]

35. Haynes, J.T.; Melson, W.G.; Kunk, M.J. Composition of biotite phenocrysts in Ordovician tephras casts doubt on the proposed trans-Atlantic correlation of the Millbrig K-bentonite (United States) and the Kinnekulle K-bentonite (Sweden). Geology 1995, 23, 847-850. [CrossRef]

36. Willman, H.B.; Kolata, D.R. The Platteville and Galena groups in northern Illinois. Circular 1978, 75. 